Reference book not to be National Bureau of Standards taken from the library.
Library, E-01 Admin. Bldg.

BUILDING SCIENCE SERIES 18 AUG $6 \quad 1971$

A」I103 07470?

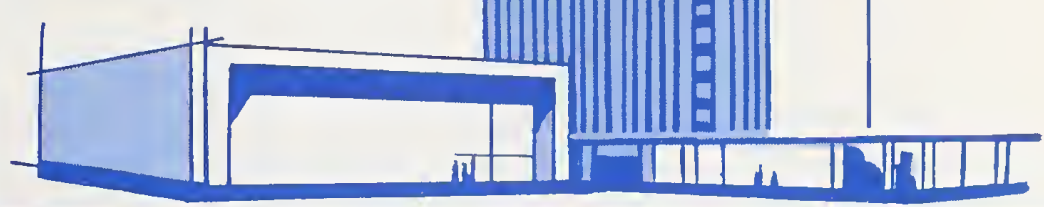

Smoke and tases

Produced by Burning Aircraft Interior Materials

U.S. DEPARTMENT OF COMMERCE National Bureau of Standards 


\section{Announcing-The Building Science Series}

The "Building Science Series" disseminates technical information developed at the Bureau on building materials, components, systems, and whole structures. The series presents research results, test methods, and performance criteria related to the structural and environmental functions and the durability and safety characteristics of building elements and systems.

These publications, similar in style and content to the NBS Building Materials and Structure Reports (1938-59), are directed toward the manufacturing, design, and construction segments of the building industry, standards organizations, officials responsible for building codes, and scientists and engineers concerned with the properties of building materials.

The material for this series originates principally in the Building Research Division of the NBS Institute for Applied Technology. Published or in preparation are:

BSS1. Building Research at the National Bureau of Standards. (In preparation.)

BSS2. Interrelations Between Cement and Concrete Properties: Part 1, Materials and Techniques, Water Requirements and Trace Elements. 35 cents

BSS3. Doors as Barriers to Fire and Smoke. 15 cents

BSS4. Weather Resistance of Porcelain Enamels: Effect of Exposure Site and other Variables After Seven Years. 20 cents

BSS5. Interrelations Between Cement and Concrete Properties: Part 2, Sulfate Expansion, Heat of Hydration, and Autoclave Expansion. 35 cents

BSS6. Some Properties of the Calcium Aluminoferrite Hydrates. 20 cents

BSS7. Organic Coatings. Properties, Selection, and Use. $\$ 2.50$

BSS8. Interrelations Between Cement and Concrete Properties: Part 3, Compressive Strengths of Portland Cement Test Mortars and Steam-Cured Mortars. 55 cents

BSS9. Thermal-Shock Resistance for Built-Ǔp Membranes. 20 cents

BSS10. Field Burnout Tests of Apartment Dwelling Units. 25 cents

BSS11. Fire Resistance of Steel Deck Floor Assemblies. 25 cents

BSS12. Performance of Square-Edged Orifices and Orifice-Target Combinations as Air Mixers. 15 cents

BSS13. Shrinkage and Creep in Prestressed Concrete. 15 cents

BSS14. Experimental Determination of Eccentricity of Floor Loads Applied to a Bearing Wall. 15 cents

BSS15. Interrelations Between Cement and Concrete Properties: Part 4, Shrinkage of Hardened Portland Cement Pastes. (In press.)

BSS16. Techniques for the Survey and Evaluation of Live Floor Loads and Fire Loads in Modern Office Buildings. (40 cents)

BSS17. Causes of Variation in Chemical Analyses and Physical Tests of Portland Cement. (In press.)

Send orders with remittance to: Superintendent of Documents, U.S. Government Printing Office, Washington, D.C. 20402. Remittances from foreign countries should include an additional one-fourth of the purchase price for postage. 
UNITED STATES DEPARTMENT OF COMMERCE - Maurice H. Stans, Secretary NATIONAL BUREAU OF STANDARDS - A. V. Astin, Director

\section{Smoke and Gases Produced by Burning Aircraft Interior Materials}

D. Gross, J. J. Loftus, T. G. Lee, and V. E. Gray

Building Research Division

Institute for Applied Technology

National Bureau of Standards

Washington, D.C.

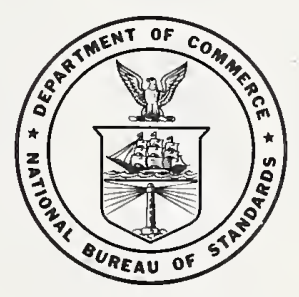

Building Science Series 18

Issued February 1969

For sale by the Superintendent of Documents, U.S. Government Printing Office

Washington, D.C. $20402-$ Price 35 cents 


\section{Contents}

1. Introduction

1. Introduction $\ldots$

2. Test methods

2.1. Material identification _............. 1

2.2. Smoke measurements _... _...

2.3. Gas analysis $\ldots \ldots$

3. Test results and analysis $\ldots \ldots \ldots$

3.1. Material identification _.

3.2. Smoke measurements _._. _ _ _ _ _ _ 4

3.3. Gas analysis _......... 8

4. Discussion ........... 9

5. Conclusions

6. References _... . .

7. Appendix 1. Gas analysis _....... 12

7.1. Colorimetric indicator tubes . .

7.2. Specific ion electrode

8. Appendix 2. Materials description

9. Appendix 3. Summary of test results - smoke and gas concentration -.- 21

10. Appendix 4. Typical smoke accumulation curves for selected materials 


\title{
Smoke and Gases Produced by Burning Aircraft Interior Materials*
}

\author{
D. Gross, J. J. Lof tus, T. G. Lee, and V. E. Gray
}

\begin{abstract}
Measurements are reported of the smoke produced during both flaming and smoldering exposures on 141 aircraft interior materials. Smoke is reported in terms of specific optical density, a dimensionless attenuation coefficient which defines the photometric obscuration produced by a quantity of smoke accumulated from a specimen of given thickness and unit surface area within a chamber of unit volume. A very wide range in the maximum specific optical density was observed. For the majority of materials, more smoke was produced during the flaming exposure test. However, certain materials produced significantly more smoke in the absence of open flaming.

During the smoke chamber tests, indications of the maximum concentrations of $\mathrm{CO}, \mathrm{HCl}$, $\mathrm{HCN}$, and other selected potentially toxic combustion products were obtained using commercial colorimetric detector tubes. A study was made of the operation, accuracy, and limitations of the detector tubes used. Measurements of the concentrations of $\mathrm{HCl}$ were also made using specific ion electrode techniques.

Qualitative identification of the major components of the original test materials was accomplished primarily by infrared absorption spectrophotometry.
\end{abstract}

Key Words: Aircraft materials; combustion products; fire tests; interior finish; smoke; toxic gases.

\section{Introduction}

Regulatory safeguards for reducing the fire hazard of transport aircraft interior materials are contained in the Federal Aviation Regulations (FAR-Part 25, amended October 24, 1967) of the Federal Aviation Administration (FAA), which specify the use of flame-resistant materials. However, no requirements exist relating to the production of smoke and potentially toxic products.

Recent accidents involving fire, and the developnient of new materials and test methods, suggested that additional technical information should be assembled. Accordingly, the FAA stud- ied the flammability and smoke characteristics of over 100 representative interior materials $[1]^{1}$, and performed full-scale fire tests within an airplane fuselage with complete cabin furnishings and interior decor under conditions simulating normal operation [2]. The present laboratory studies are a part of FAA Project No. 510-001-11X, Hazardous Combustible Characteristics of Cabin Materials, and were undertaken with the primary objective of providing measurements on the generation of smoke and decomposition products using a recently developed smoke test chamber [3].

\section{Test Methods}

\subsection{Material Identification}

Qualitative identification of the major components of the materials prior to test was accomplished primarily by infrared absorption spectrophotometry. This involved preparing a specimen in either film or solid pellet form, with or without potassium bromide, suitable for obtaining an infrared absorption spectrum. In some cases, solvent extraction and separation were necessary in order to obtain a suitable film. Except

* The work reported in this paper was sponsored by the Federal Aviation Administration, Washington, D.C. under Contract No. FA66NF-AP-7, Project No. 510-001-11X for wools, which were identified by nitration tests, and other spot tests which were employed for cellulosic materials, most materials were identified by comparison of their infrared absorption spectra with reference spectra of known compositions. When some estimate of the percentage composition of blends or mixtures was possible, this was included and listed in order of major to minor components. For fabric blends, valid quantitative estimates are usually very difficult to make. Poly (vinyl chloride) (PVC) and poly (vinylidene chloride) polymers are difficult to detect specifically

\footnotetext{
1 Figures in brackets indicate the literature references on page 11.
} 


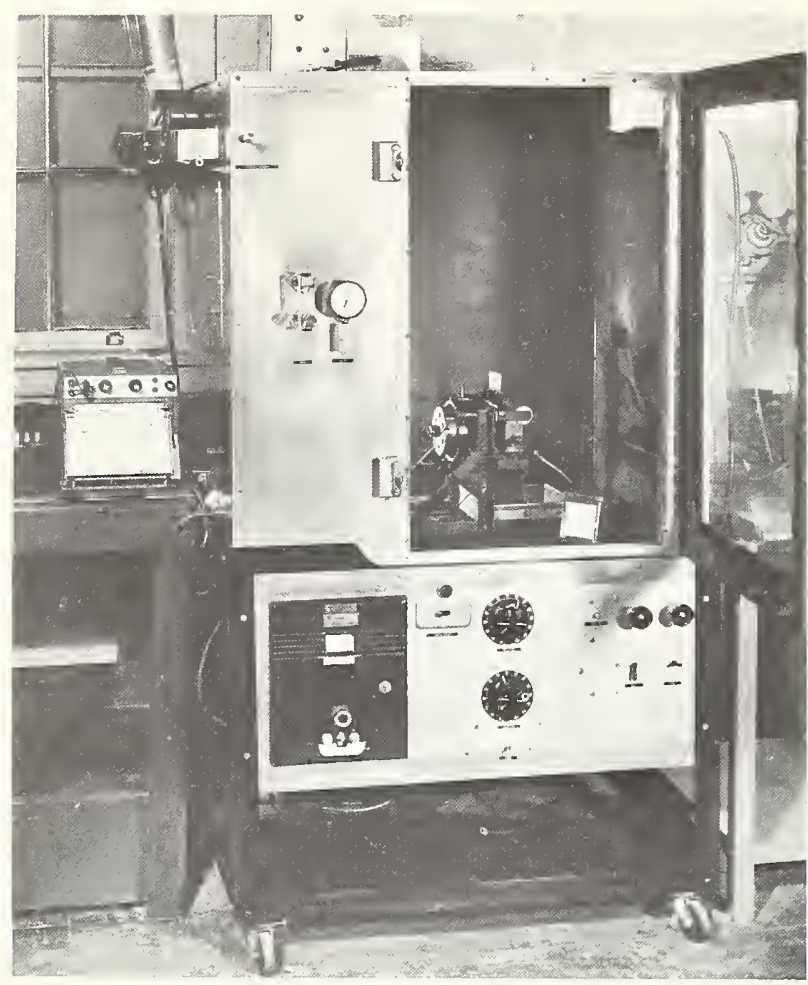

FIGURE 1. Smoke test chamber.

by infrared techniques because they have weak absorption bands and because pigments, fillers and polymer components with which they are mixed generally have overlapping spectral bands. As much as 20 to 40 percent of PVC or poly (vinylidene chloride) could go undetected.

Generic names are given in all cases, even though the spectra for some materials were so similar to reference spectra identified by trade name from the literature that very little doubt existed as to source.

\subsection{Smoke Measurements}

The smoke level was determined by measuring the progressive attenuation of a light beam passed through the smoke aerosol within an enclosed smoke chamber (see figs. 1 and 2). Smoke is reported in terms of specific optical density, a dimensionless attenuation coefficient which deines the amount of smoke accumulated from a specimen of unit surface area in terms of its photometric obscuration over unit path length within a chamber of unit volume. For the typical application in which the material is to be used as an interior finish (e.g. on walls, ceilings, floors), the fire-exposed surface area of the specimen governs its smoke-production behavior. Specimen thickness (unit weight) correspond to the materials as supplied and used. The basis and limitation of the method were described in detail in a recent paper
[3], which also discussed the general relationship between the measured specific optical density and the level of smoke through which a light (or lighted exit sign) may be seen.

The tests involved a thermal irradiation ex. posure of $2.5 \mathrm{~W} / \mathrm{cm}^{2}\left(2.2 \mathrm{Btu} / \mathrm{ft}^{2} \cdot \mathrm{s}\right)^{2}$ normal to the exterior surface of a $3 \times 3$ in specimen and were performed under both flaming and nonflaming (smoldering) exposure. To induce open flaming in the former case, a small pilot $<0.35$ $\mathrm{SCFH}$ natural gas diffusion flame in a $1 / 16$ in i.d tube) was applied at the base of the specimen These conditions were selected to provide a wide range of smoke levels for different types of ma. terials. The size of the specimen and the volume of the chamber were such that complete oxidation of practically all materials could occur without appreciable decrease in oxygen content. Materials were furnished by FAA and were tested using typical section in the thickness supplied.

Optical density, defined as $D=\log \frac{100}{T}$ (where $T=$ percent light transmission), is the single most characteristic measure of the obscuring quality of a smoke. Specific optical density, $D_{s}$ is a property of a specimen of given thickness

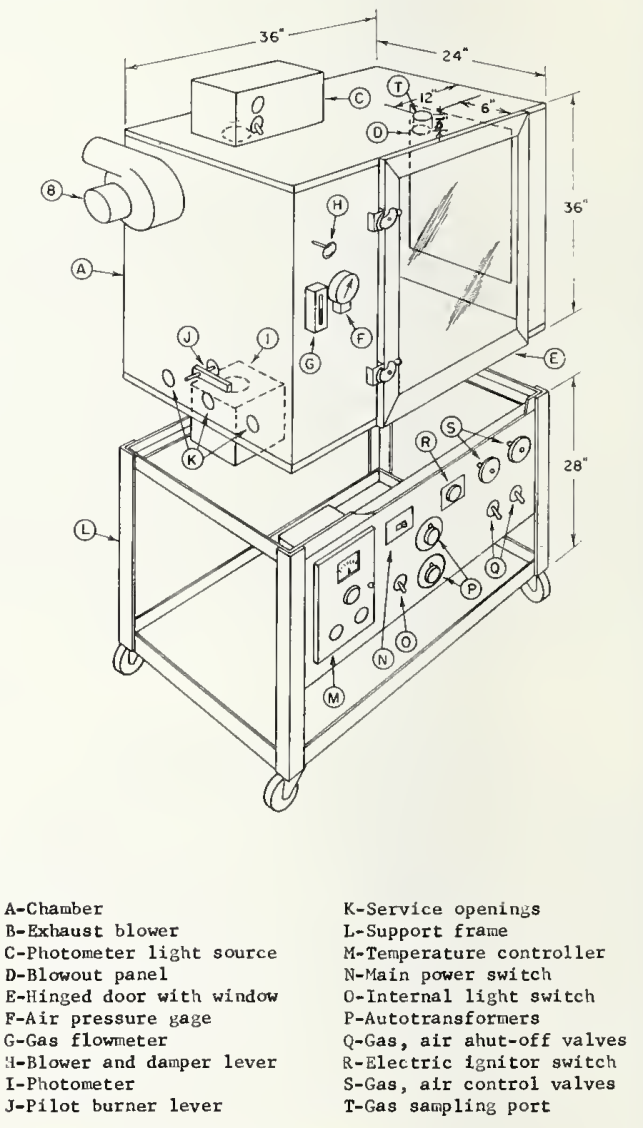

FIgURE 2. Smoke chamber assembly.

21 British thermal unit $(B t u)=1055$ watt second $(W \cdot s)$. 
and represents the optical density measured over unit path length $(L)$, within a chamber of unit volume $(V)$, produced from a specimen of unit surface area $(A)$. Thus, $D_{s}=D \frac{V}{A L}=\frac{V}{A L}$ $\log \frac{100}{T}$

For the test chamber, $V=18 \mathrm{ft}^{3}\left(0.510 \mathrm{~m}^{3}\right)$, $A=0.0456 \mathrm{ft}^{2}\left(0.00424 \mathrm{~m}^{2}\right)$, and $L=3 \mathrm{ft}(0.914$ $\mathrm{m})$. Ideally, the change in $D_{s}$ with time during the smoke accumulation process will depend only upon the thickness of the specimen, its chemical and physical properties, and the exposure conditions. The results are reported in terms of (a) maximum (total) srinoke accumulation, $D_{m}$, (b) maximum rate of smoke accumulation (over a 2-min period), $R_{m}$, and (c) the time period, $t_{c}$, to reach a "critical" specific optical density of 16 , under the test conditions.

However, there are definite limitations to the use of specific optical density for extrapolation and comparison with other box volumes, specimen areas and photometric systems, and for extension to human visibility. The degree to which such extensions are valid depend upon a number of major assumptions: the smoke generated is uniformly distributed and is independent of the amount of excess air available and of any specimen edge effects; coagulation and deposition of smoke is similar regardless of the specimen size, or the size and shape of the chamber; for any given smoke the optical density is linearly related to concentration; and human and photometric vision through light-scattering smoke aerosols, expressed in terms of optical density, are similar.

\subsection{Gas Analysis}

Indications of the concentrations of gaseous products were obtained by drawing a sample of the gas mixture in the smoke test chamber through commercial colorimetric gas detector tubes and reporting results on the basis of the manufacturers calibrations for the selected gases [4]. Essentially, a colorimetric tube is a small-bore glass tube containing a chemical packing which changes color when exposed to a specific component of a gas mixture, and the length of color stain is related to the concentration of that component for a given quantity and rate of flow of gas. Layers of precleaning granules and a plug to absorb interfering gases and to control the sample flow rate are generally provided. Sampling was done several times during each smoke test using a small syringe or bellows pump designed to aspirate a measured volume of gas each stroke. The gas detector tube was inserted into the smoke chamber from the top, and was situated 3 in below the top surface of the chamber (approximately 25 in above the level of the specimen). In some instances an attempt was made to extend the range of these indicators by drawing less than the recommended gas volume through them and reporting results on the basis of individual laboratory calibrations, as reported in a later section. More detailed discussion of product gas analysis by colorimetric detector tubes and by specific ion electrode are presented in appendix 1 .

Indicator tubes were used to detect $\mathrm{CO}, \mathrm{HCN}$, $\mathrm{HCl}, \mathrm{HF}, \mathrm{SO}_{2}, \mathrm{NO}+\mathrm{NO}_{2}, \mathrm{NH}_{3}, \mathrm{Cl}_{2}$ and $\mathrm{COCl}_{2}$, since these gases have generally been considered toxicologically hazardous compared with other possible components. However, these are not necessarily the only potentially toxic components released. No attempts were made to determine high concentrations of $\mathrm{CO}_{2}$ or low concentrations of $\mathrm{O}_{2}$, or to consider the type, size, or concentration of smoke particles in toxicological terms. Information on the analytical limits for the tubes used, and references to the toxic hazard limits of these gases are discussed in appendix 1. Where $\mathrm{HCl}$ was one of the products, in many cases the gas was also absorbed in water and analyzed by a chlorine ion electrode to provide a more accurate indication at high concentrations.

\section{Test Results and Analysis}

\subsection{Material Identification}

Appendix 2 is a list of materials, showing numerical designation, thickness, unit weight, type, use, and approximate chemical composition of the major components. Of the 141 materials studied, these may be divided into the following groups:

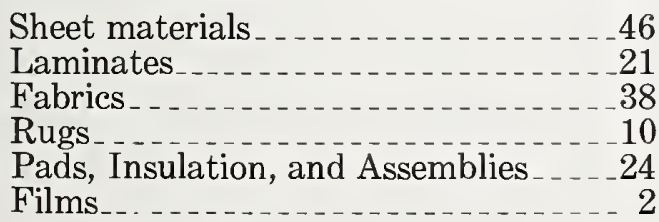

Of the 38 fabrics composed of woven fibers, only a few were essentially natural fibers (cotton and wool), a few were composed of a mixture of natural and artificial fibers, but the bulk of the fabrics were made from 100 percent artificial fibers, including acrylics, modacrylics, polyesters, polyamides (nylon-type), vinyl, and glass.

of the sheet and laminate materials, approximately one-half were composed entirely or predominantly of poly vinyl chloride (PVC), and the remaining sheet and laminate materials were composed of acrylonitrile-butadiene-styrene (ABS), methyl methacrylate, and other copolymers, blends, and varieties of polymers. The rugs tested included wool, modacrylics, polyamide (nylon and aromatic types), and polypropylene. Of the pads used for seats, there were several urethane foam materials and one rubber (chloroprene). The materials used as ceiling or bulkhead insulation in- 


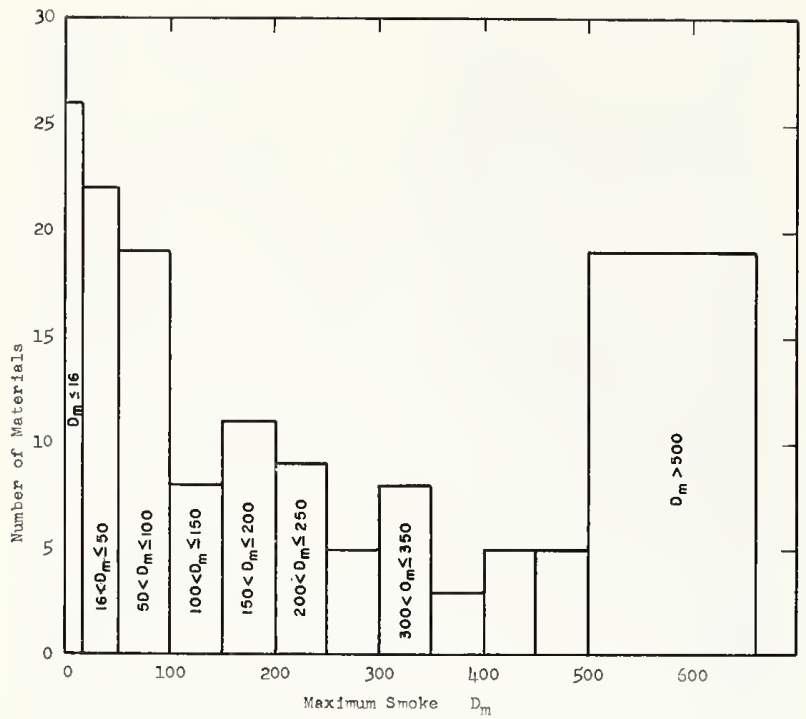

FIGURE 3. Frequency distribution of maximum smoke values. Flaming exposure-140 materials.

cluded mainly glass fiber materials or a paper honeycomb sandwich.

\subsection{Smoke Measurements}

Smoke measurements are summarized in appendix 3 in terms of the maximum smoke accumulation $\left(D_{m}\right)$, the maximum rate of smoke accumulation $\left(R_{m}\right)$ and the time $\left(t_{c}\right)$ to reach a specific optical density of 16 for both flaming and smoldering exposure. These results represent averages of duplicate tests (with few exceptions). For $D_{m}$ values up to 200 , the standard deviation was 11.8 for flaming and 9.2 for nonflaming tests. Smoke buildup curves for typical flaming and smoldering tests on selected types of materials are shown in appendix 4.

A wide range of $D_{m}$ values was measured. Slightly more than 15 percent of the materials produced smoke corresponding to a $D_{m}=16$ or less, for both flaming and smoldering exposures. These included materials composed of glass, asbestos, aromatic polyamide, polyimide plus others, but many of these materials were very thin (lightweight). $D_{m}$ values in excess of 200 were recorded for flaming and smoldering exposures on approximately 20 percent of the materials.

For flaming exposure of 140 materials, frequency distribution histograms of the maximum smoke values are shown in figure 3 for all materials, and in figure 4 within the classification groups: (a) fabrics, (b) rugs, (c) sheets, films, and laminates, and (d) pads, insulations, and assemblies. Of the materials in the $D_{m} \leq 16$ category, 16 were fabrics, 6 were sheets or films, and 4 were glass or asbestos fiber insulations.

With one exception, all materials in the $D_{m} \leq 16$ category under flaming conditions were also $D_{m} \leq$ 16 under nonflaming conditions.

Figures 5, 6, and 7 comprise a complete histogram showing smoke and toxic gas concentrations for flaming and nonflaming exposures on each material based on the data in appendix 3. Materials have been arranged according to classification by groups, by composition, and by generally increasing weight within each subgroup.

It should be noted that only the "front" side of a material was exposed, and that specimens exhibited a very wide range in their physical and thermal behavior during flaming and nonflaming exposure. Materials which melted at fairly low temperatures, including nylon, polysulfone, and polyethylene, flowed to the bottom or dripped off the sample holder in varying degrees, resulting in less smoke. Some materials evaporated fairly rapidly before extensive decomposition or combustion took place. All urethane foam materials produced more smoke under smoldering exposure than with flaming exposure, except in one instance where the material was noted to shrink into a corner of the holder and was, therefore, subjected to less radiation. Rubber (chloroprene), ABS, methacrylate, and PVC materials nearly always produced more smoke under flaming exposure. Under thermal radiation exposure alone, elastomers generally formed a bell-shaped protrusion at their center through which gaseous products streamed out rapidly. The maximum smoke level depends upon the thickness (and density) of the specimen, and for some materials $D_{m}$ may be expected to increase with thickness but not always in direct proportion [3].
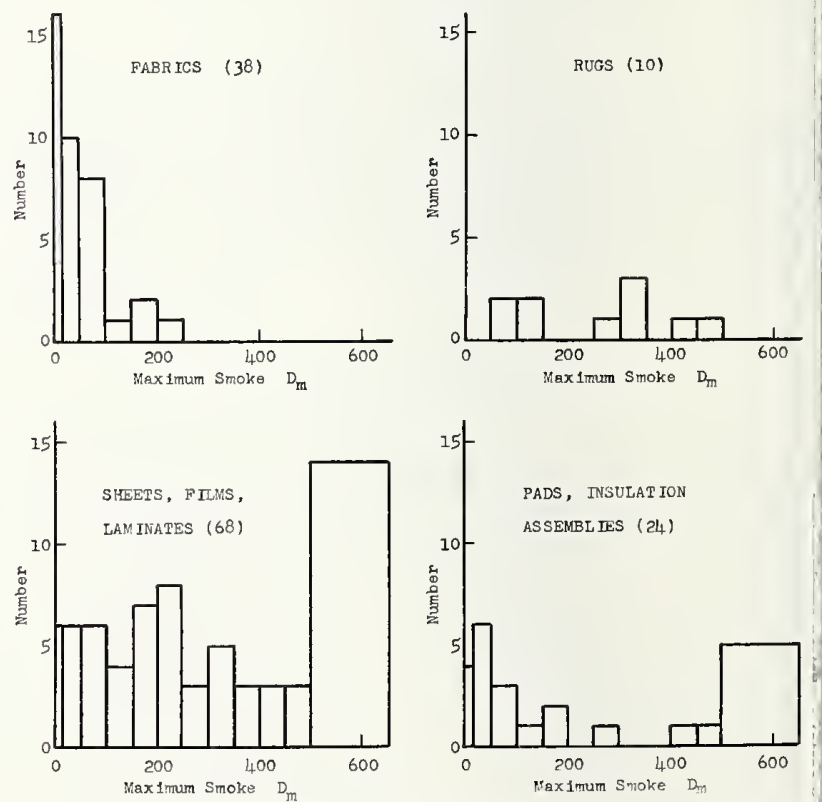

FIGURE 4. Frequency distribution of maximum smoke values by groups. Flaming exposure - 140 materials. 


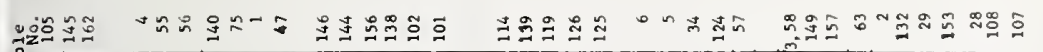

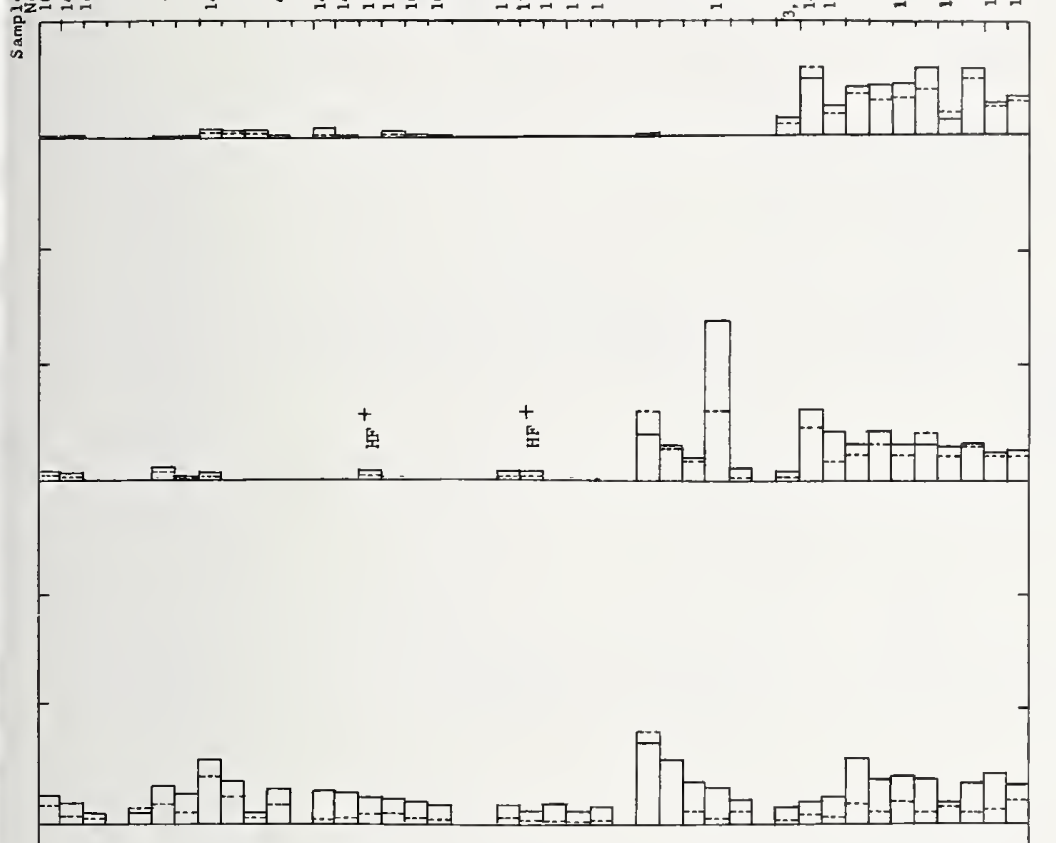

ant

\section{(1)} to (1) (1)

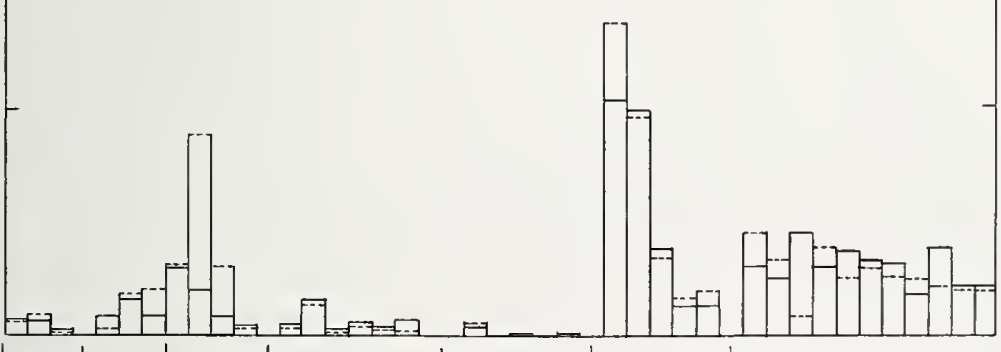

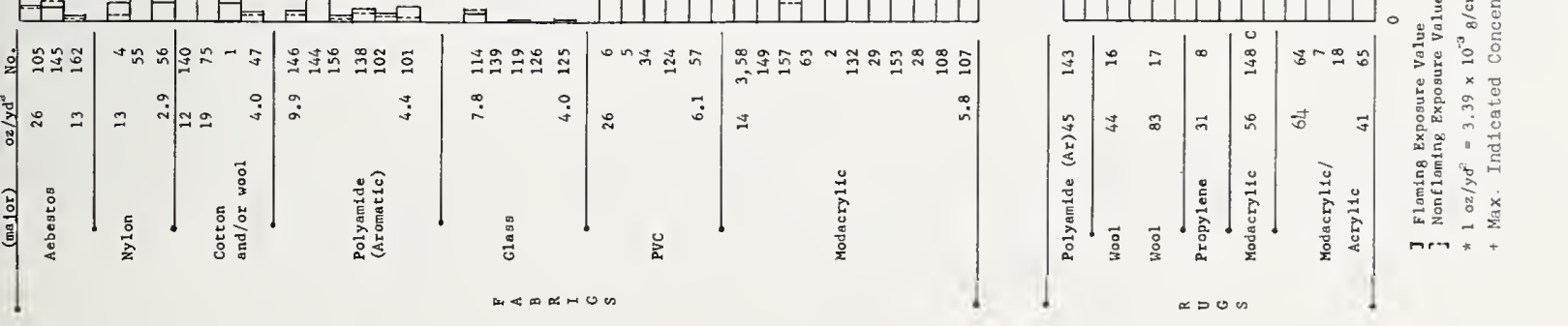

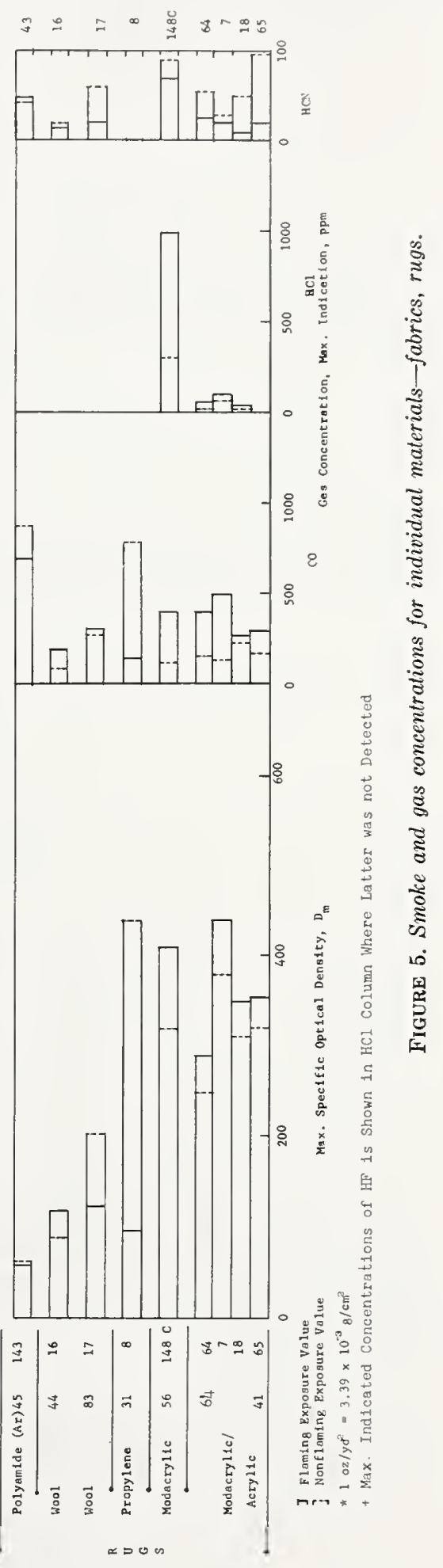




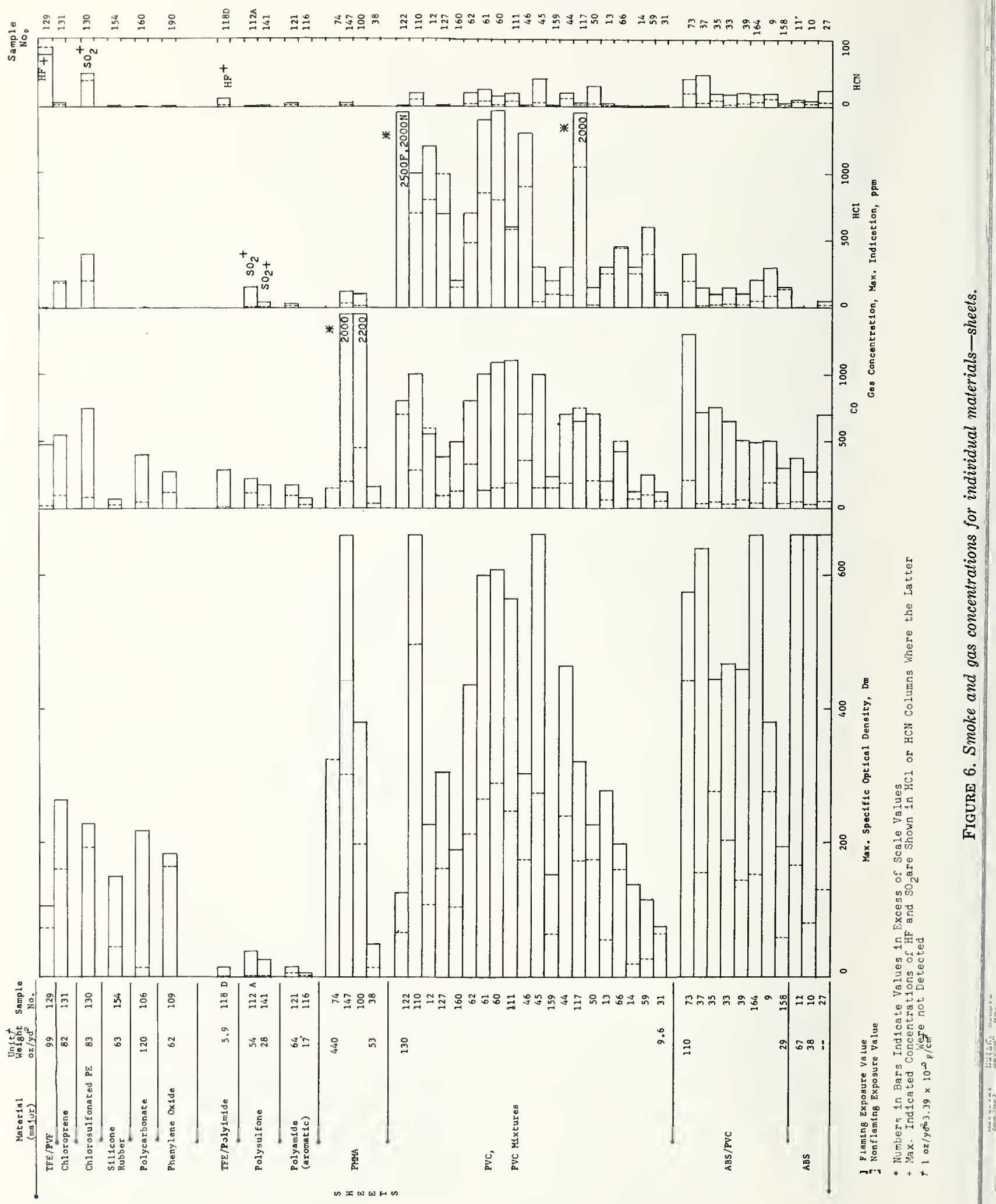




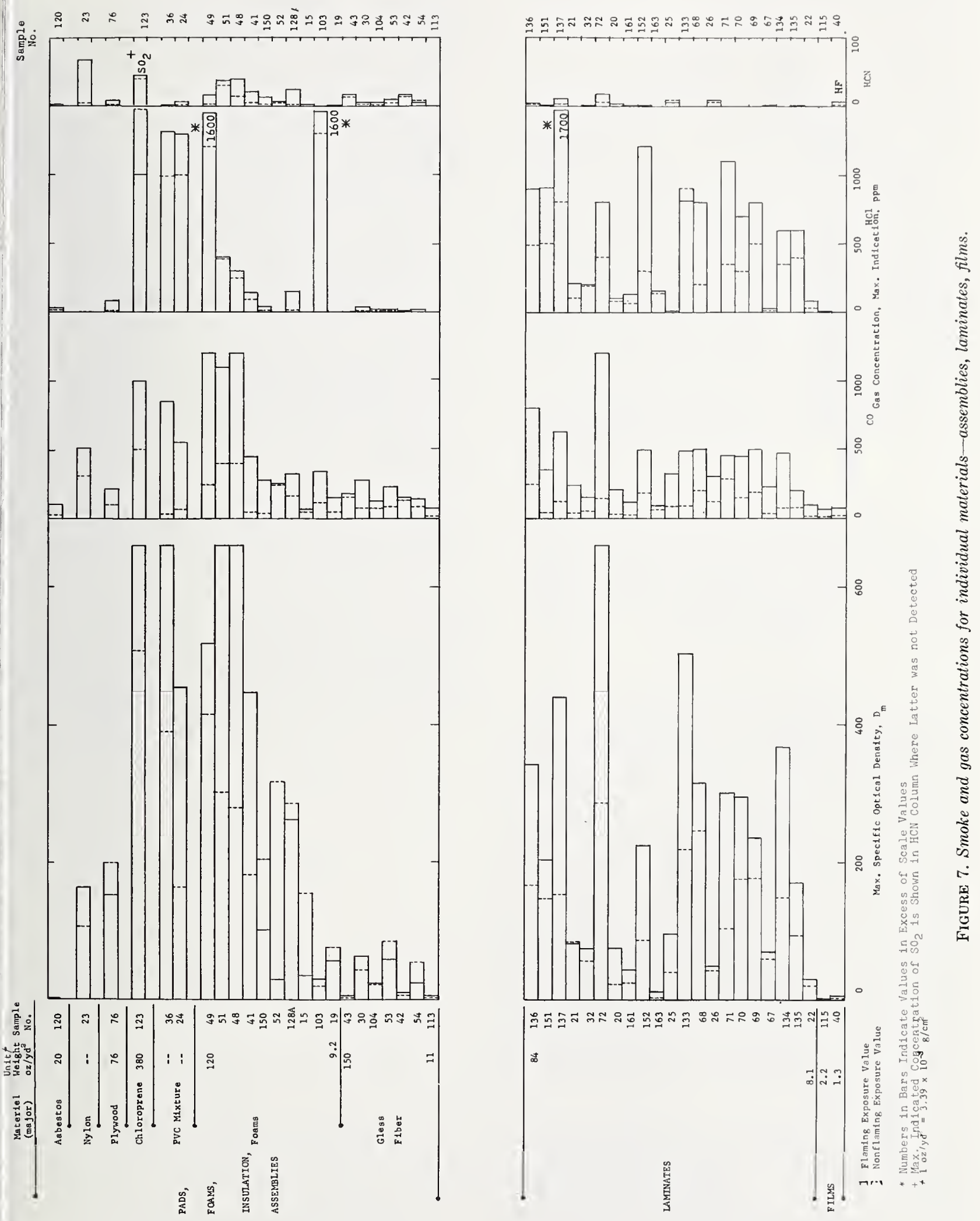




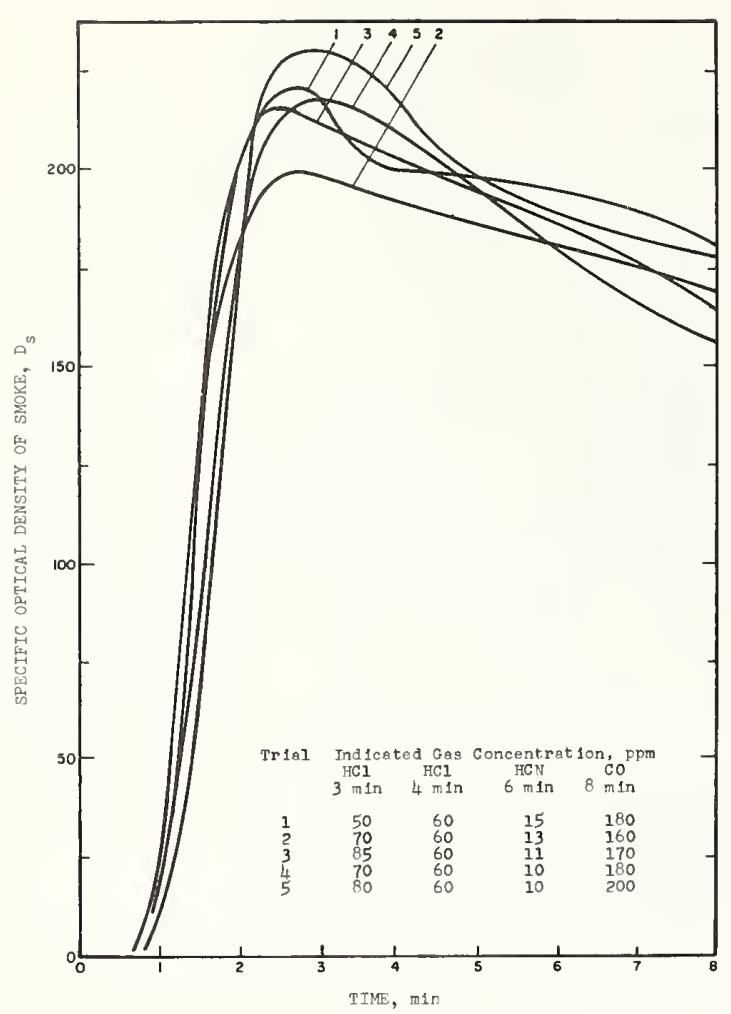

Figure 8. Reproducibility of smoke and gas concentration indications. Sample No. 44 (PVC/PVA/ABS) nonflaming exposure.

\subsection{Gas Analysis}

"Maximum" indicated concentrations of gases are listed in appendix 3 along with the smoke data. These values are based on the average of two separate determinations, except that additional tests were made where large discrepancies (greater than a factor of 2) between duplicate values were obtained. Unlike the measurement of optical density of smoke, which is recorded continuously to obtain a maximum, the concentrations of selected components was measured periodically. Particularly for components which change rapidly, therefore, the indicated concentration values may not necessarily be the true maximum values. For the materials tested, the highest indicated concentrations were $2200 \mathrm{ppm}$ CO, 2500 ppm $\mathrm{HCl}$, and $90 \mathrm{ppm} \mathrm{HCN}$. These concentrations refer to the same exposed area of specimen and chamber volume used, but to a wide range of specimen weights.

Since the primary objective of this study was to ascertain approximate values, no extensive efforts were made to improve reproducibility. As a test of reproducibility for a PVC material (specimen No. 44), 5 separate smoldering exposure tests were conducted with the results shown in figure 8 . This figure shows the five replicate smoke curves and a tabulation of indicated gas concentrations at spe- cific times during each test. The measurement' ranges were on the order of \pm 20 percent for $\mathrm{CO}$ and $\mathrm{HCN}$ and \pm 30 percent for $\mathrm{HCl}$, and such variations may be considered typical of the maximum indicated concentration values under the test conditions.

Because the plastic materials studied were from many manufacturers and generally contained plasticizers, fillers, and other additives, it is difficult to relate quantitatively gaseous product concentrations with polymer composition. In general $\mathrm{HCl}$ was produced by polyvinyl chloride and modacrylic materials, HF from polyvinyl fluoride $\mathrm{HCN}$ from wool, urethane, ABS, and modacrylics and $\mathrm{SO}_{2}$ from polysulfone and rubber materials CO was produced by almost all the samples ir varying amounts depending on the type of ma terial.

It has been shown [5] that the amount of : given gas produced during pyrolysis and its rate of generation are strongly temperature dependent Thus, any materials or processes which affect the temperature profile across the specimen (e.g. filler; and plasticizers which produce surface crusting intumescence, etc.), could readily influence thi concentration of gaseous products. For certair materials, higher concentrations of some gase: may be produced under conditions of insufficien air, e.g. 10 percent oxygen [6].
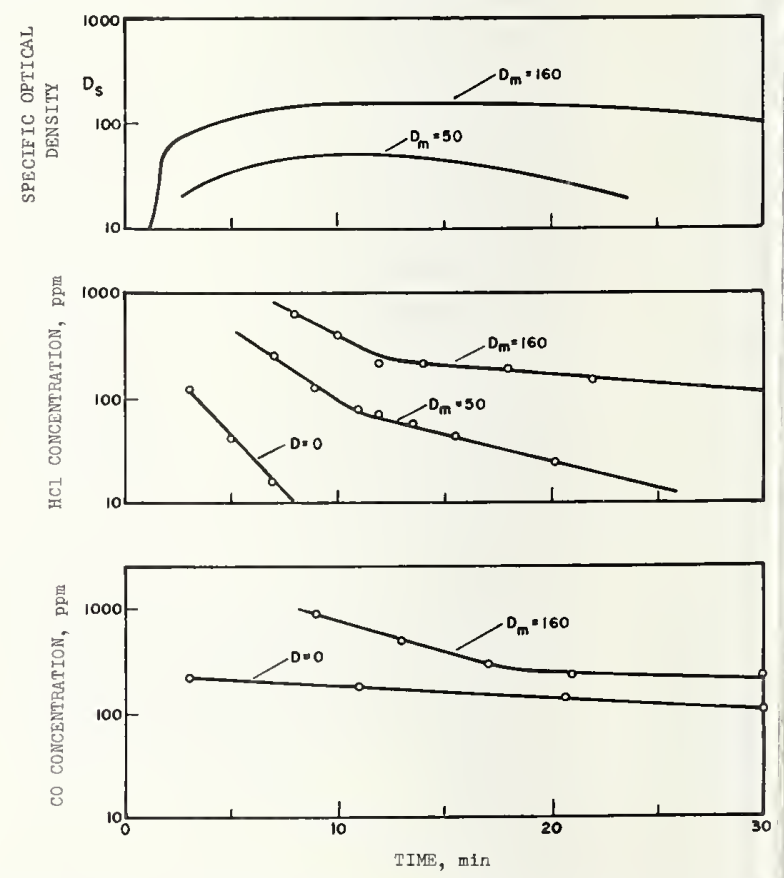

Figure 9. Comparative decay in $\mathrm{HCl}$ and $\mathrm{CO}$ concentr tions for several smoke density levels.

Top: Smoke, nonflaming exposure, 2 selected PVC/PVA materials

Center: $\mathrm{HCl}$ concentration. Prior to taking readings, $220 \mathrm{~cm}^{3} / \mathrm{min}$ of $\mathrm{H}$ was introduced in chamber over 3 -min period

Bottom: $\mathrm{CO}$ eoncentration. Prior to taking readings, $190 \mathrm{~cm}^{3} / \mathrm{min}$ of $\mathrm{C}$ was introduced in chamber over 3 -min period 
Sampling was performed sequentially, proceeding generally from $\mathrm{HCl}$ and $\mathrm{HF}$ to $\mathrm{HCN}$ to $\mathrm{CO}$, and was initiated when optical density of the smoke approached its peak. This procedure was followed because of the fairly rapid decay in halogen acid concentration resulting from adsorption on (and reaction with) moisture, smoke particles, and chamber surfaces. To facilitate subsequent data comparison, sampling for $\mathrm{HCl}$ and $\mathrm{HF}$ was generally initiated at the beginning of the minute close to the maximum smoke level, and at 2-min intervals thereafter for other gases.

Gas temperature at the sampling tube inlet generally ranged from 46 to $52^{\circ} \mathrm{C}$ ( 115 to $126^{\circ} \mathrm{F}$ ), the higher temperatures occurring during flaming tests on heavier materials. Due to the cooling effect of the precleaning layers of the indicator itubes, the temperature of the gases passing the indicating layers were within the prescribed maximum temperature limits. The sampling rate was generally unaffected by either the elevated temperature of gases or by heavy smoke particle concentrations.
Hydrogen chloride is generally released rapidly during combustion or pyrolysis of polyvinyl chloride, modified acrylics and other retardant-treated materials [7, 8]. Maximum levels were generally higher under flaming compared to smoldering exposure conditions presumably due to the higher temperature involved and the resultant greater rate of release. The $\mathrm{HCl}$ concentration changed rapidly as a result of its high reactivity, solubility in water, and adsorption on smoke particles and wall surfaces. The type of surface as well as the total area of the interior walls have a pronounced influence on the adsorption and settling (or decay) rate of $\mathrm{HCl}$ and smoke. To illustrate the decay of both $\mathrm{HCl}$ and $\mathrm{CO}$, a suitable concentration of the pure component was metered into the bottom of the chamber under both smoke-free $(D=0)$ and smoke-filled conditions. Figure 9 shows the indicated concentrations of $\mathrm{HCl}$ and $\mathrm{CO}$. In these tests involving smoldering specimens only, the gas concentration levels are obviously higher because a portion of the gas is introduced by combustion. The decay rates are also higher.

\section{Discussion}

In the work described in this report, it was presumed that the test specimens were representative in thickness and density of the materials intended for actual use as interior finishes. For a few materials supplied in thicknesses greater than 1 in, the test specimen was trimmed to a thickness of 1 in to fit the size of the specimen holder. It should be evident that the density of smoke, the concentration of gaseous products, and the heat release characteristics are properties of the specimen as tested and will be different for other thicknesses and densities.
Limitations were previously noted to the use of specific optical density for extrapolating the smoke density measured in the laboratory test to other enclosure volumes and surface areas. Within these limitations, the relationship between the measured value of $D_{s}$ and the geometrical factor $\frac{V}{L A}$ for various values of light transmission (or optical density) is shown in figure 10. The optical density level through which a lighted exit sign may be seen can vary over wide limits depending on the

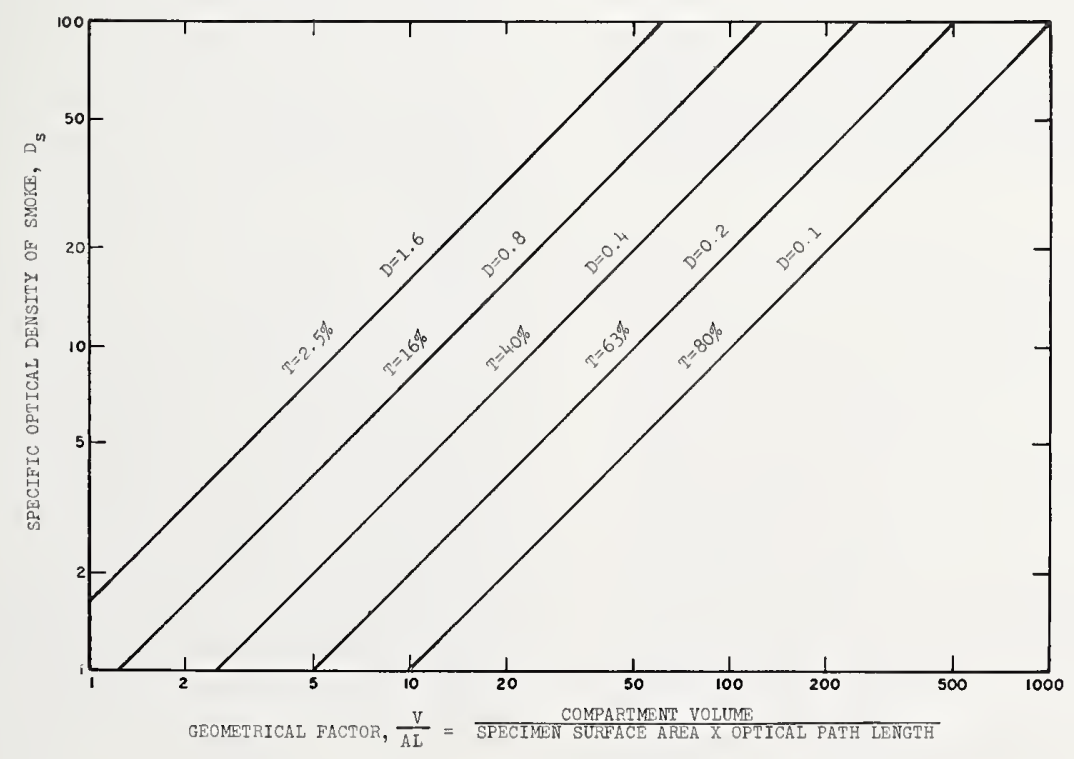

FIGURE 10. Specific optical density versus geometrical factor for five selected light transmission values. 
general illumination level, on the contrast threshold and the extent to which the observer's eyes have been dark-adapted, as well as on the irritating nature of the smoke. In figure 10, five lines are shown for transmission values ranging from 80 to 2.5 percent (optical density 0.1 to 1.6 ) corresponding to a wide range of visual limits [3].

Using this figure, sample computations have been made in Table 1 for 3 selected values of $D_{s}$. If it is assumed that a lighted exit sign can be seen when the transmission is down to 40 percent (optical density 0.4), and an aircraft cabin has a volume of $10,000 \mathrm{ft}^{3}$ within which smoke is uniformly dispersed, then Table 1 shows the estimated area $A$ of material, the smoke from which may just begin to limit seeing the exit sign at various distances $L$.

Up to this point, only geometrical factors have been considered, but time is certainly important, and the choice of a critical specific optical density for each material can presumably also be based on a prescribed time period which is sufficiently long to permit escape or defensive action. From appendix 3 , it may be noted that the time periods to attain a critical specific optical density of 16 ranged from 0.2 to over $20 \mathrm{~min}$. It was previously noted [3] that a specific optical density of 16 could represent a possible critical limit.

Although the three factors, total smoke accumulation $\left(D_{m}\right)$, maximum rate of smoke accumulation $\left(R_{m}\right)$, and the time period to reach a "critical" optical density $\left(t_{c}\right)$, are directly related to the smoke obscuration hazard, their relative weighting is not entirely obvious. One suggestion for a single overall hazard index based on the results of this test was made in the appendix of reference 3 . However, it should be emphasized that additional experimental verification would be desirable prior to establishing rigorous smoke hazard limits for interior materials.

This study was concerned with the limited problem of measuring the optical density of smoke as it relates to the obscuration of human vision. No attempt was made to evaluate complications due to eye irritations, to respiratory effects from

TABLE 1. Critical (projected) surface area of material burned in $10,000 \mathrm{ft}^{3}$ volume

(for optical density $=0.4$ )

\begin{tabular}{|c|c|c|c|}
\hline $\begin{array}{c}\text { Specific } \\
\text { optical } \\
\text { density } D_{s}\end{array}$ & $\frac{\frac{V}{A L}}{(\text { for } O D=0.4 \text { ) }}$ & $\begin{array}{c}\text { Light } \\
\text { distance } \\
\qquad L\end{array}$ & $\begin{array}{c}\text { Specimen } \\
\text { area } \\
A\end{array}$ \\
\hline $\begin{array}{l}10 \\
10 \\
10 \\
10\end{array}$ & $\begin{array}{l}25 \\
25 \\
25 \\
25\end{array}$ & $\begin{array}{r}3 \mathrm{ft} \\
10 \\
30 \\
100\end{array}$ & $\begin{array}{c}133 \mathrm{ft}^{2} \\
40 \\
13.3 \\
4\end{array}$ \\
\hline $\begin{array}{l}50 \\
50 \\
50 \\
50\end{array}$ & $\begin{array}{l}125 \\
125 \\
125 \\
125\end{array}$ & $\begin{array}{r}3 \\
10 \\
30 \\
100\end{array}$ & $\begin{array}{c}26.7 \\
8 \\
2.67 \\
0.8\end{array}$ \\
\hline $\begin{array}{l}100 \\
100 \\
100 \\
100\end{array}$ & $\begin{array}{l}250 \\
250 \\
250 \\
250\end{array}$ & $\begin{array}{r}3 \\
10 \\
30 \\
100\end{array}$ & $\begin{array}{r}13.3 \\
4.0 \\
1.3 \\
0.4\end{array}$ \\
\hline
\end{tabular}

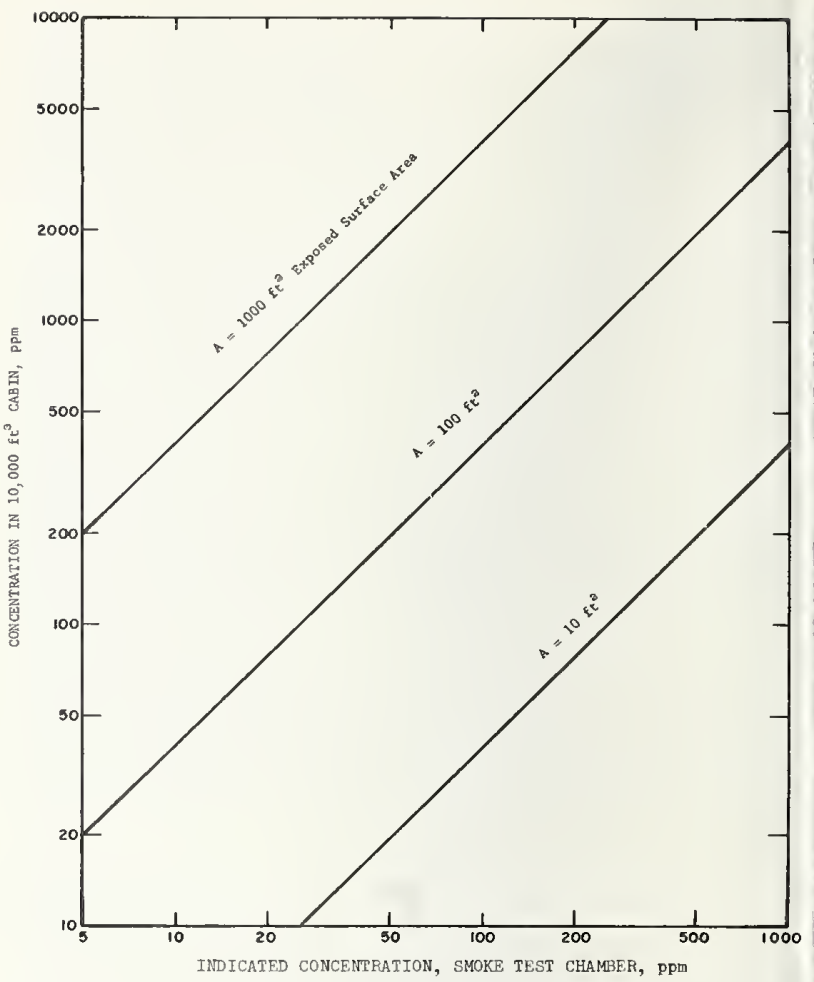

FIgURE 11. Gas concentration in 10,000 $\mathrm{ft}^{3}$ cabin based on indicated concentration in smoke test chamber.

inhaled smoke particles, or to hysteria or associated physiological or psychological factors.

The indicated concentrations of gaseous products listed in appendix 3 represent values measured at the sampling location and are associated with the prescribed exposure conditions on a specimen of given exposed area (2\%/16 in square) within a totally enclosed chamber of $18 \mathrm{ft}^{3}$ volume. Specimens were tested in the thickness and weight supplied, which varied over a wide range. Concentration measurements were made periodically from the time when the optical density of the smoke approached its peak. Any realistic evaluation of the gas concentrations likely to be encountered in a real fire situation must take into account actual areas and thicknesses of the materials exposed and the volumes in which the gases are dispersed. Also of importance are the rate of fire growth, the effects of adsorption and reaction, the extent of ventilation, dilution, and/or application of extinguishing agents, and other factors outside the scope of this study. Where specimen area and chamber volume are the only variables and uniform mixing is assumed, an approximate relationship between the gas concentration measured in the smoke chamber and the projected concentration within a much larger chamber, such as an aircraft cabin, is given by

$$
C_{\text {cabin }}=C_{\text {test }} \frac{V_{t}}{A_{t}} \frac{A_{c}}{V_{c}} .
$$


This simply scales concentration $(C)$ in direct roportion to the area $A$ of specimen involved nd in inverse proportion to the chamber volume 7 . As an example, the gas concentration in a $0,000 \mathrm{ft}^{3}$ cabin is shown in figure 11 for a series f lines corresponding to surface areas of 10,100 , nd $1,000 \mathrm{ft}^{2}$.

It should be noted that such scaled estimates ssume similar (or uniform) distribution of the aseous components, and large differences may esult in the case of active gases and vapors which tend to be adsorbed on surfaces, e.g. HF and $\mathrm{HCl}$, and gases and vapors which tend to stratify in layers.

Finally, it should be noted that relationships between the indicated concentrations measured in the smoke chamber and physiological or toxicological effects are also outside the scope of this study. The table of toxicological data, assembled from open literature sources has been included for reference purposes only. Information on the combined, or synergistic, effects of several noxious components (including smoke $\mathrm{r}$ articles) is apparently very limited.

\section{Conclusions}

Based upon the tests performed and an evalution of the results, the following conclusions have ieen reached:

1. Materials currently used as interior furnishings for aircraft cabins, and those being considered for future use, vary considerably in their production of smoke and potentially toxic products under simulated fire conditions.

2. The laboratory test method for generating smoke and measuring its optical density appears to be a useful tool for the quantitative classification of materials, and for the possible establishment of revised fire safety standards and criteria for controlling smoke production. Optical density is the single most characteristic measure of the visual obscuring quality of a smoke.

3. For evaluating smoke production, both smoldering and active flaming conditions should be considered. For the majority of materials, more smoke was produced during the flaming exposure test. However, certain materials produced significantly more smoke in the absence of open flaming.

4. Within the limitations and assumptions cited, the specific optical density of smoke measured in the laboratory may be extrapolated to cabin volumes and surface areas of combustible furnishings in order to provide guidelines for cabin area limitations, or to estimate time periods available for escape or defensive action.

5. Indications of the concentrations of potentially toxic combustion products can be conveniently and inexpensively obtained during the smoke production test using calibrated commercial colorimetric tubes; however, these are suitable only where interferences by other gases are absent, and where precision is not of primary importance. The specific ion electrode is also a convenient method of measuring the concentrations of halogen acid gases. Furthermore, if an attempt is made to relate the indicated concentrations measured in the smoke chamber in terms of toxicological limits, caution must be excercised. It is essential that proper consideration be given to (a) scaling of the areas and volumes in the proposed situation, (b) the integrated dosage where concentration varies with time, (c) the synergistic effects of several components (and smoke particles), and (d) the effects of relative humidity, elevated temperature, stratification, adsorption on surfaces, and physiological factors not considered in this study.

\section{References}

[1] Marcy, J. F., Nicholas, E. B., and Demaree, J. E., Flammability and Smoke Characteristics of Aircraft Interior Materials. Federal Aviation Agency Technical Report ADS-3, Jan. 1964.

[2] Marcy, J. F., A Study of Air Transport Passenger Cabin Fires and Materials, Federal Aviation Agency Technical Report ADS-44, Dec. 1965.

[3] Gross, D., Loftus, J. J., and Robertson, A. F., A Method for Measuring Smoke from Burning Materials, American Society for Testing Materials Special Technical Publication 422, 1967.

[4] a. Scott Draeger Multi-Gas Detector, distributed by Scott Aviation Corporation, Lancaster, N.Y.

b. MSA Colorimetric Gas Detector Tubes, Mine Safety Appliances Co., Pittsburgh, Pa.

c. Kitagawa Precision Gas Detector, Unico Model No. 400, Union Industrial Equipment Corp., Port Chester, N.Y.

[5] Madorsky, S. L., Thermal Degradation of Organic Polymers, $315 \mathrm{pp}$. (Interscience (Wiley) 1964).
[6] Ausobsky, S., Evaluation of the combustion gases of plastics, (in German), VFDB Zeitschrift 16, 58-66, 1967.

[7] Coleman, E. H. and Thomas, C. H., The products of combustion of chlorinated plastics, J. Appl. Chem. 4, 379-383, 1954.

[8] Fish, A., Franklin, N. H., and Pollard. R. T., Analysis of toxic gaseous combustion products, J. Appl. Chem. 13, 506-9, 1963.

[9] Kusnetz, H. L., Saltzman, B. E., and Lanier, M. E., Calibration and evaluation of gas detector tubes, Am. Ind. Hyg. Assoc. J. 21, 361-373, 1960.

[10] Saltzman, B. E., Preparation and analysis of calibrated low concentrations of sixteen toxic gases, Anal. Chem. 33, 1100-1112, 1961.

[11] Saltzman, B. E. and Gilbert, N., Am. Ind. Hyg. Assoc. J. 20, 379-386, 1959.

[12] Rechnitz, G. A. and Kresz, M. R., Anal. Chem. 38, 1786,1966 . 


\section{Appendix 1. Gas Analysis}

\subsection{Colorimetric Indicator Tubes}

The manufacturer provided general information on the detector tubes regarding their measuring range, interfering reactions, reuse and the effects of temperature and relative humidity. The upper and lower limits of the measuring ranges of these tubes and some references to the toxicological limits of these gases are summarized in table 2 . With good quality control during manufacture and frequent calibration, specific tubes can give meaningful results. However, certain shortcomings may be noted. These include:

1. Variation of packing density within the tube and nonuniformity of indicator gel among the tubes. Since the adsorption rate of a sample gas by the gel depends primarily on the reacting surface area available per length of tube, a variable packing density would affect reproducibility.

2. Certain gases and vapors are not adsorbed by the precleaning layer but react similarly with the indicator as the gas of interest to produce an unexpected interference.

3. The transition zone of the discolored stain front makes it difficult to judge the exact demarcation line and thus introduces errors.

These shortcomings can be minimized, for example, by frequent calibration to establish probable sources of errors, by knowing the specific interfering gases in the sample not absorbed by the precleaning layer and the sensitivity of the tube to these gases, and by determining the concentration of the interference gas, if any, found in the sample. With cumulative experience on using the tubes both during calibration and sampling, the error in judging the line of demarcation of the discolored section by an operator can be minimized. The merit of the colorimetric tubes as in any other analytical method should be judged by performance on a specific gas. Sensitivity, accuracy, and interference effects depend on the chemical system used in the tube and they are obviously different for different gases. An extensive review of some of the techniques and problems associated with these tubes is given by Kusnetz, et al. [9].

The advantages of the indicator tubes are convenience and simplicity, yielding immediate results with the avoidance of transfer vessels and other sampling problems. In the hands of an experienced operator, reasonable accuracy can be attained.

Of the colorimetric tubes used, tubes for four compounds have been calibrated and examined for interferences and temperature effect. For calibration purposes low concentrations of $\mathrm{HCl}$ or HCN were prepared from a flow dilution system suggested by Saltzman [10]. The system consists of an asbestos plug which serves as a flow-limiting device [11], and a mixing chamber as shown in figure 12. Tubing to the asbestos flowmeter is $1 \mathrm{~mm}$ i.d. polytetrafluoroethylene tubing to minimize dead volume. The pressure regulating cylinder was filled with concentrated $\mathrm{H}_{2} \mathrm{SO}_{4}$. Flows were calibrated by attaching a graduated $0.1 \mathrm{ml}$ pipet to the meter outlet and timing with a stopwatch the movement of a drop of mercury past the graduations. Flow rates as low as $0.01 \mathrm{~cm}^{3} / \mathrm{min}$ can be achieved with good long term stability.

The degree of dilution of pure $\mathrm{HCl}$ from the tank was controlled by the asbestos plug and the diluting gas metered by a rotameter. Mixture concentration could be varied from 10 to 1000 ppm. A needle valve controlled the flow rate to the indicator tube. The pressure drop across the colorimetric indicator during calibration was balanced by applying an appropriate vacuum at the other end of the tube. This arrangement avoids creating any disturbance to the diluting system when the tube is inserted to start a calibration.

Low concentrations of $\mathrm{HCN}$ were generated by aeration of a 4.6 molar solution of $\mathrm{KCN}$ in a midget impinger. A thermostated water bath surrounding the bubbler and air supply condenser maintained a temperature of $30^{\circ} \mathrm{C}\left(86^{\circ} \mathrm{F}\right)$. The system produced an output of $100 \mathrm{ppm}$ and further dilution was necessary for lower concen-

TABLE 2. Measuring range of colorimetric indicator tubes and toxicological data for selected gases

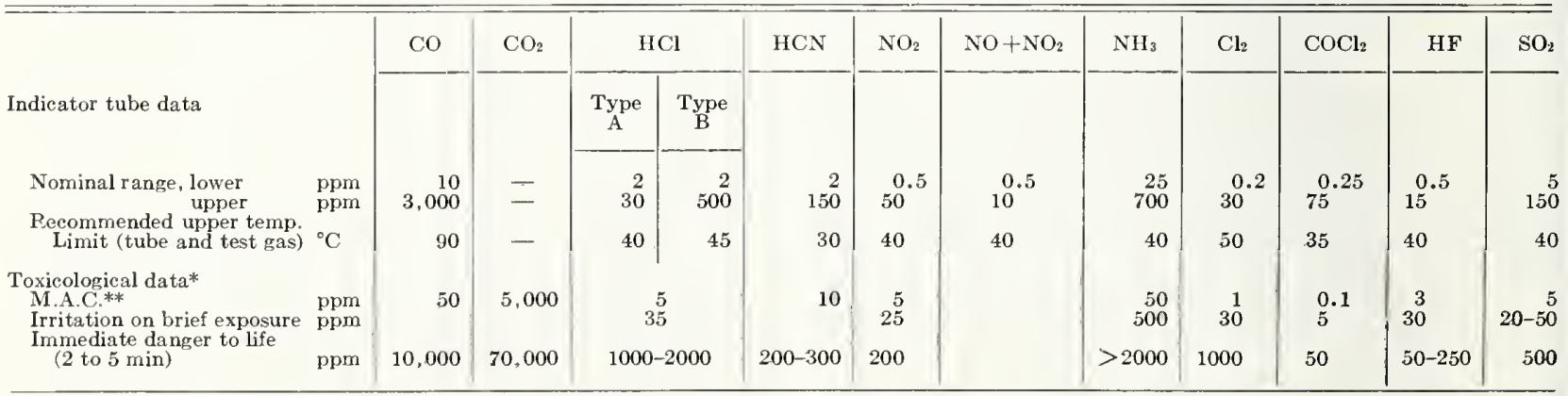

* Based on the following references:

Henderson, Y., Haggard, H. W.: Noxious Gases. (Reinhold Publishing Corp., New York 1943)

Elkins, H.'B.: The Chemistry of Industrial Toixiology (John Wiley \& Sons, Inc., New York 1959)

American Conference of Governmental Industrial Hygienists, Document of Threshold Values, Cincinnati, Ohio 45202 (1966 edition).

** Maximum average atmospheric concentration for 8-hr daily exposure adopted by American Conference of Governmental Industrial Hygienists, 1966. 
Figure 12. Flow dilution and calibration arrangement.

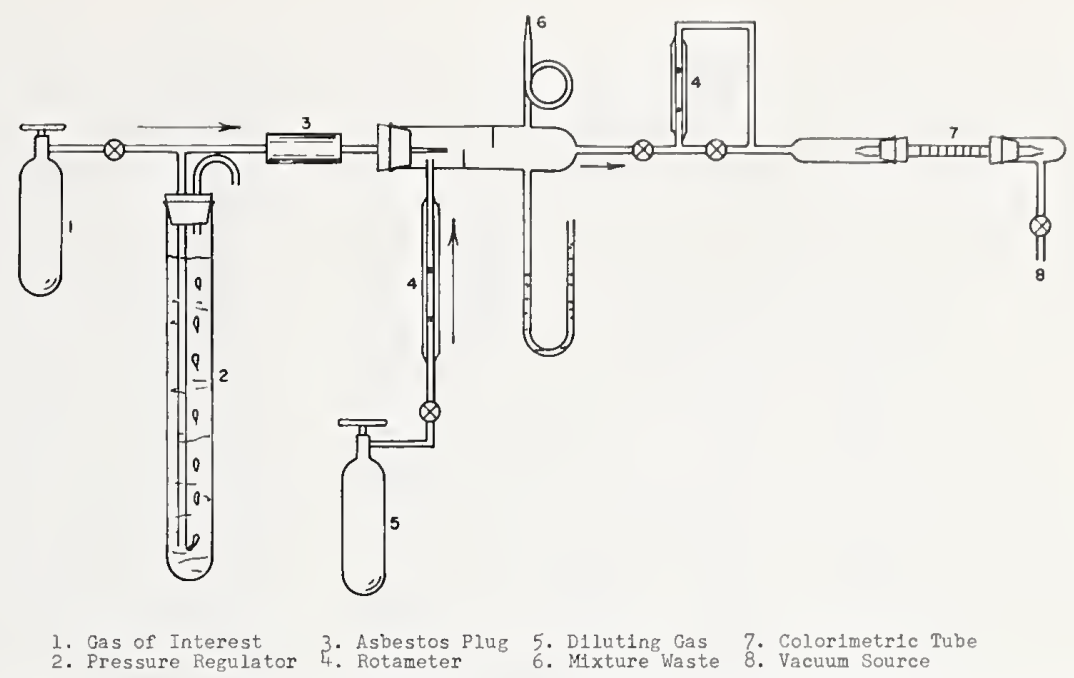

trations. Both $\mathrm{HCl}$ and $\mathrm{HCN}$ systems were very stable and consistent.

A static method using an FEP polytetrafluoroethylene 5-mil-thick collapsible bag was used to generate low concentrations of nonreacting gases. Under this arrangement, the sample gas was deposited by a gas-tight microsyringe and diluted with air or other gases from a 1-liter syringe. This method is not applicable to $\mathrm{HCl}$ or $\mathrm{HCN}$ because of losses resulting from adsorption, but gave satisfactory results with $\mathrm{CO}$ from 10 to $1000 \mathrm{ppm}$.

\subsection{Specific Ion Electrode}

A permeable membrane electrode for chloride ions (after Pungor) described recently [12] was

used in a system to determine the $\mathrm{HCl}$ concentration in a gas sample potentiometrically. This method has higher accuracy, range, and reliability than that of colorimetric indicator tubes. Its working range is between 20 and $20,000 \mathrm{ppm}$ for a $100 \mathrm{~cm}^{3}$ gas sample. For lower concentrations, a larger sample must be used.

In practice, the highly water-soluble $\mathrm{HCl}$ gas and vapor in the $100 \mathrm{~cm}^{3}$ sample was totally absorbed when the sample flowed at a rate of $100 \mathrm{~cm}^{3} / \mathrm{min}$ through polytetrafluoroethylene tubing (5.3 mm i.d.) containing about $40 \mathrm{mg}$ of loosely packed glass wool wetted with $0.1 \mathrm{~cm}^{3}$ water. The exposed glass wool was carefully transferred to a polytetrafluoroethylene cup of small

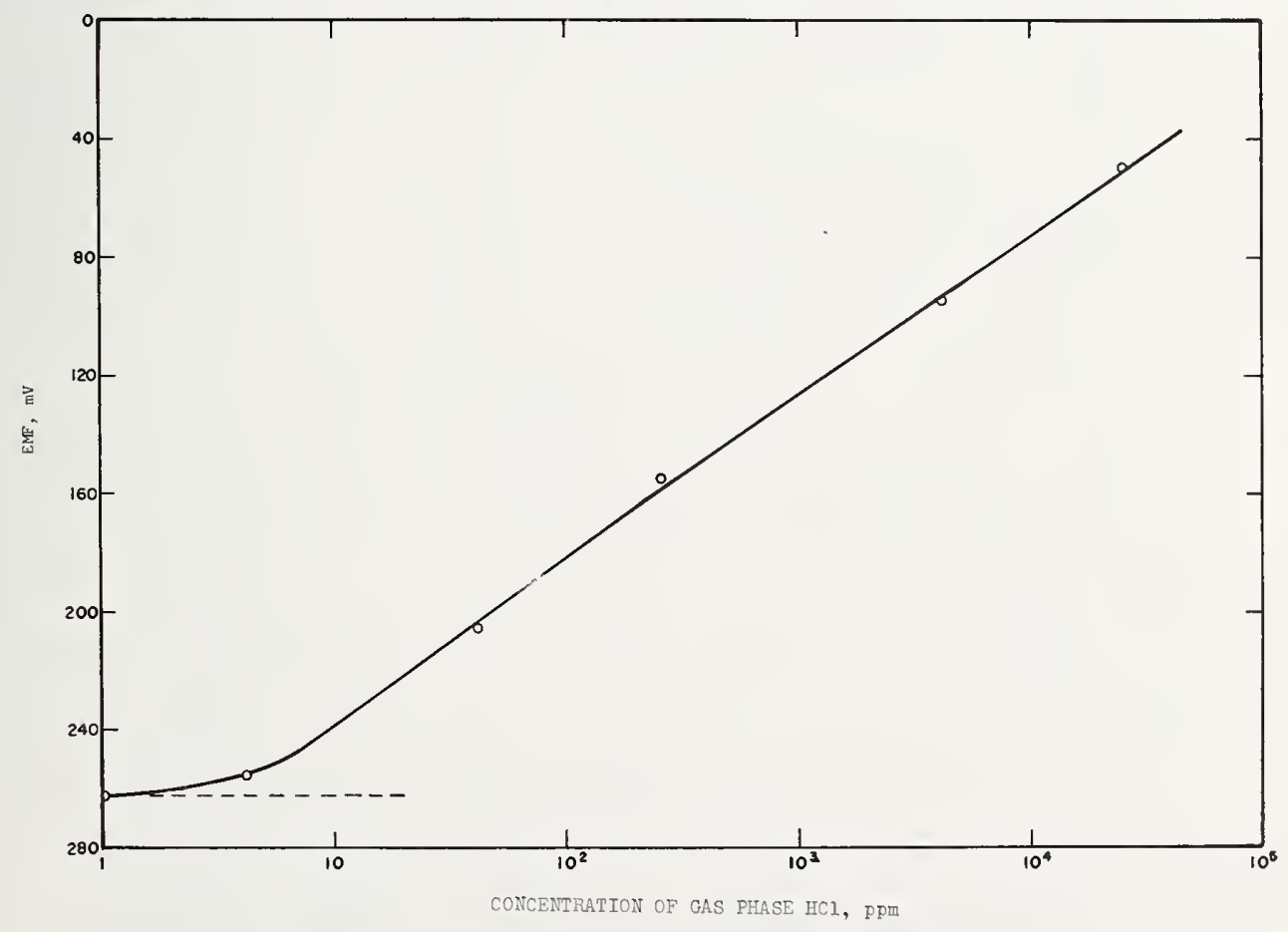

Figure 13. Measured emf as a function of $\mathrm{HCl}$ concentration in gas phase based on $\mathrm{HCl}$ in $100 \mathrm{~cm}^{3}$ sample absorbed by $1 \mathrm{~cm}^{3}$ of water. 


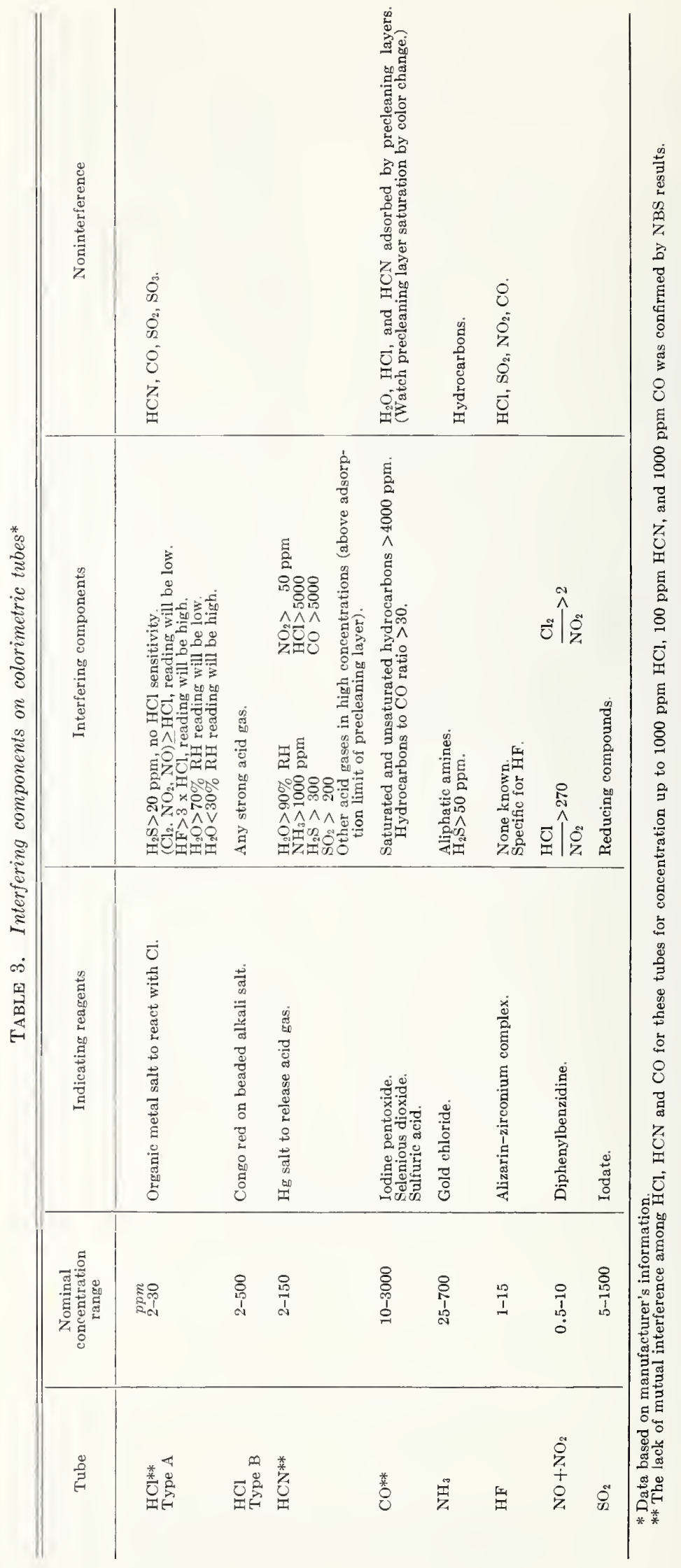


internal volume. Water was added to make a total solution of $1 \mathrm{~cm}^{3}$ before insertion of the specific ion electrode, and a low-leakage, smalldiameter-tip, conventional calomel- $\mathrm{KCl}$ reference electrode. A high impedance differential voltmeter or an expanded scale $\mathrm{pH}$ meter may be used to measure the emf between the electrodes. The specific electrode has a sensitivity limit of $10^{-5}$ mole per liter for chloride ion in solution and an equilibrium response time of about $1 \mathrm{~min}$. It consists essentially of a polymeric silicone rubber membrane impregnated with particles of silver chloride precipitate. The membrane covers the tip of a small diameter glass tube filled with a chloride solution. Figure 13 shows the calibration curve of emf in $\mathrm{mV}$ and $\mathrm{HCl}$ concentration in ppm calculated on the basis of a $100 \mathrm{~cm}^{3}$ gas sample absorbed in a $1 \mathrm{~cm}^{3}$ solution. The curves were based on measurements made with solutions of known $\mathrm{HCl}$ concentrations.

Known interferences of bromide or iodide ions may be considered negligible if their concentrations are less than one-tenth of the chloride ion concentration [12]. In most fire gas or smoke chamber analyses no interference would be expected. In cases where the concentration of bromide ions is likely to be the same order as that of chloride, a bromide specific electrode can be used. This electrode is not affected by chloride ion concentrations as high as 50 times that of bromide.

Table 3 shows the type of indicator reagents used in the detector tubes. It also lists the known components and concentrations which would cause sufficient interference to give erroneous readings.
The precleaning layer serves to remove the interfering components and the table shows the maximum concentrations that can be tolerated. The data are based on information furnished by the tube manufacturer as well as NBS data showing the lack of mutual interference among the major components of $\mathrm{HCl}, \mathrm{HCN}$ and $\mathrm{CO}$. Except for $\mathrm{H}_{2} \mathrm{~S}$ which apparently poisons the reactive surface in the $\mathrm{HCl}$ tube, other interferences did not significantly alter the usefulness of those colorimetric tubes in the present smoke chamber study.

Table 4 shows some of the basic and calibration data for the colorimetric indicator tubes used. Included are the concentration ranges for which the tubes are rated and the sample volume and measured sampling rate for which the predetermined scale calibration holds. The length of indicating layer compared with the maximum of the concentration range indicates the resolution of the tube. The transition zone is a subjective estimate of the length between complete color change to no change which affects the reading error. The calibration ratios were based on the average of three separate runs for each of the stated concentrations. The method of preparation of an actual concentration of a single component in an atmospheric air mixture was given in the previous section. Unlike a previous study where several disinterested observers were asked to judge the demarcation front of the color change [9], the present results were based on the observation of one individual only. With the exception of the type $\mathrm{B} \mathrm{HCl}$ tube which was +90 percent in error, all other errors fell within $a \pm 20$ percent range.

TABLE 4. Colorimetric indicator tubes

\begin{tabular}{|c|c|c|c|c|c|c|c|c|c|c|}
\hline \multicolumn{4}{|c|}{ Basic data (supplied by Mfr.) } & \multicolumn{7}{|c|}{ Calibration data (NBS) } \\
\hline \multirow{2}{*}{ Tube } & \multirow{2}{*}{$\begin{array}{c}\text { Concentration } \\
\text { Range }\end{array}$} & \multirow{2}{*}{$\begin{array}{l}\text { Sample } \\
\text { volume }\end{array}$} & \multirow{2}{*}{$\underset{\text { rate }}{\text { Sampling }}$} & \multicolumn{2}{|c|}{ Packing length } & \multicolumn{2}{|c|}{ Transition zone } & \multicolumn{3}{|c|}{ Concentration } \\
\hline & & & & Precleaning & Indicating & Length & Error & Actual & Indicated $^{\mathrm{b}}$ & Error \\
\hline & $p p m$ & $\mathrm{~cm}^{3}$ & $\begin{array}{l}\text { seconds } \\
\text { per stroke }\end{array}$ & $m m$ & $m m$ & $m m$ & $\%$ & $p p m$ & $p p m$ & $\%$ \\
\hline $\begin{array}{l}\mathrm{HCl} \\
\text { Type A }\end{array}$ & $\begin{array}{c}2-30 \\
{ }^{a} 10-300\end{array}$ & $\begin{array}{r}1000 \\
100\end{array}$ & 11 & 30 & 60 & 4 & \pm 7 & $\begin{array}{r}5 \\
25 \\
86 \\
200\end{array}$ & $\begin{array}{r}30 \\
95 \\
180\end{array}$ & $\begin{array}{l}+20 \\
+10 \\
-10\end{array}$ \\
\hline $\begin{array}{l}\mathrm{HCl} \\
\text { Type B }\end{array}$ & $\begin{array}{r}2-100 \\
20-500\end{array}$ & $\begin{array}{l}500 \\
100\end{array}$ & 30 & 0 & 65 & 2 & \pm 3 & 300 & 570 & +90 \\
\hline $\mathrm{CO}$ & $\begin{array}{c}10-300 \\
100-3000\end{array}$ & $\begin{array}{r}1000 \\
100\end{array}$ & 27 & 40 & 50 & 2 & \pm 4 & $\begin{array}{r}50 \\
100 \\
200 \\
500 \\
1000\end{array}$ & $\begin{array}{r}120 \\
220 \\
500 \\
1000\end{array}$ & $\begin{array}{r}+20 \\
+10 \\
0 \\
0\end{array}$ \\
\hline $\mathrm{HCN}$ & $\begin{array}{c}2-30 \\
10-150\end{array}$ & $\begin{array}{l}500 \\
100\end{array}$ & 10 & 30 & 50 & 6 & \pm 8 & $\begin{array}{r}\mathbf{5} \\
30 \\
\mathbf{7 5}\end{array}$ & 35 & +20 \\
\hline HF & $\begin{array}{l}1-15 \\
5-150\end{array}$ & $\begin{array}{r}1000 \\
100\end{array}$ & 5 & 0 & 60 & 3 & \pm 5 & 16 & 14 & -13 \\
\hline $\mathrm{NO}+\mathrm{NO}_{2}$ & $\begin{array}{l}0.5-10 \\
85-50\end{array}$ & $\begin{array}{l}500 \\
100\end{array}$ & 9 & 30 & 60 & 5 & \pm 8 & & & \\
\hline $\mathrm{SO}_{2}$ & $\begin{array}{c}5-150 \\
50-1500\end{array}$ & $\begin{array}{r}1000 \\
100\end{array}$ & 12 & 0 & 65 & 4 & \pm 6 & & & \\
\hline $\mathrm{NH}_{3}$ & $25-700$ & 1000 & 9 & 0 & 75 & 3 & \pm 4 & & & \\
\hline
\end{tabular}

a Concentration range extended by use of individual calibration (not furnished by the manufacturer).

b Average readings of three separate tubes. 


\section{Appendix 2. Material Description}

\section{Abbreviations}

Code

F1,F2-Fabric (uncoated, coated)

R1,R2-Rug (unpadded, padded)

$\mathrm{S} 1, \mathrm{~S} 2, \mathrm{~S} 3$ - Sheet (flexible, semi-rigid, rigid)

L1,L2,L3-Laminate (flexible, semi-rigid, rigid)
Designation

C Coated

UC Uncoated

F Flexible

SR Semi-rigid

$\mathrm{R}$ Rigid

$\mathrm{P}$ Padded

UP Unpadded

FR Fire-retardant treated
Composition

ABS Acrylonitrile/butadiene/styrene

PETP Polyethylene terephthalate polyester

PMMA Poly methyl methacrylate

PYA Poly vinyl acetate

PVC Poly vinyl chloride

\begin{tabular}{|c|c|c|c|c|c|c|c|}
\hline No. & Code & Thickness & $\begin{array}{l}\text { Unit* } \\
\text { weight }\end{array}$ & $\begin{array}{l}\text { Color and } \\
\text { surface }\end{array}$ & Designation & $\begin{array}{l}\text { Present or } \\
\text { intended use }\end{array}$ & Material identification \\
\hline & & Inch & $o z / y d^{2}$ & & & & \\
\hline 1 & $F-1$ & 0.035 & 11 & Light-hlue & Fahric (CC) & Drapery & Wool/cotton (75:25). \\
\hline 2 & $\mathrm{~F}-\mathrm{I}$ & 0.030 & 9.6 & Light-hlue & Fahric (UC) & Drapery & Modacrylic. \\
\hline 3 & $F-1$ & 0.055 & 14 & $\begin{array}{l}\text { Blue (multi- } \\
\text { color } \\
\text { pattern) }\end{array}$ & Fabric (UC) & Drapery & Modacrylic/nylon/cotton. \\
\hline 4 & $F-1$ & 0.050 & 13 & $\begin{array}{l}\text { Tan } \\
\text { Corduroy }\end{array}$ & Fahric ( $\left.\mathrm{U}^{-} \mathrm{C}\right)$ & Epholstery & Polyamide (nylon type). \\
\hline 5 & $\mathrm{~F}-2$ & 0.030 & 12 & $\begin{array}{l}\text { Blue } \\
\text { Matte }\end{array}$ & Fahric (C) & Upholstery & $\begin{array}{l}\text { Polyvinylchloride/methyl methacrylate/ester } \\
\text { plasticizer on cotton. }\end{array}$ \\
\hline 6 & $\mathrm{~F}-2$ & 0.045 & 26 & $\begin{array}{l}\text { Gold } \\
\text { Matte }\end{array}$ & Fabric (C) & Epholstery & $\begin{array}{l}\text { Polyester plasticizer (phthalate-type), possible } \\
\text { PTC, on cotton. }\end{array}$ \\
\hline 7 & $\mathrm{R}-2$ & 0.33 & 62 & $\begin{array}{l}\text { Blue/gray } \\
\text { Loop }\end{array}$ & Rug (P) & Flooring & $\begin{array}{l}\text { Pile: Modacrylic/acrylic. } \\
\text { Backing: Polyester fher. } \\
\text { Pad: Polyester urethane foam. }\end{array}$ \\
\hline 8 & $\mathrm{R}-1$ & 0.18 & 31 & $\begin{array}{l}\text { Blue/green } \\
\text { Loop }\end{array}$ & Rug (LP) & Flooring & $\begin{array}{l}\text { Pile: Copolymer } \\
\text { poly(propylene-butylene). } \\
\text { Center: Cellulosic. } \\
\text { Backing: Polyethylene. }\end{array}$ \\
\hline 9 & S-1 & 0.046 & 46 & $\begin{array}{l}\text { Tan } \\
\text { Matte }\end{array}$ & Sheet (F) & $\begin{array}{l}\text { Panel and door } \\
\text { covering }\end{array}$ & PVA/ABS, china clay pigmented possible PVC. \\
\hline 10 & S-2 & 0.045 & 38 & $\begin{array}{l}\text { Dark gray } \\
\text { Matte }\end{array}$ & Sheet (SR) & $\begin{array}{l}\text { Food trays, } \\
\text { mindow } \\
\text { frames }\end{array}$ & $\operatorname{ABS}(\sim 25 \%: 10 \%: 65 \%)$ \\
\hline 11 & $S-3$ & 0.080 & 67 & $\begin{array}{l}\text { Green } \\
\text { Polished }\end{array}$ & Sheet $(R)$ & $\begin{array}{l}\text { Food trays, } \\
\text { mindow } \\
\text { frames }\end{array}$ & $\operatorname{ABS}(\sim 25: 10: 65)$ \\
\hline 12 & $S-3$ & 0.080 & 81 & $\begin{array}{l}\text { Tan } \\
\text { Matte }\end{array}$ & Sheet $(R)$ & $\begin{array}{l}\text { Ceilings, seat } \\
\text { panels }\end{array}$ & $\begin{array}{l}\text { Copolymer: PVC/poly methyl methacrylate } \\
(\sim 9505)\end{array}$ \\
\hline 13 & $s-2$ & 0.030 & 26 & $\begin{array}{l}\text { Gold } \\
\text { Shiny }\end{array}$ & Sheet (SR) & Trim & $\begin{array}{l}\text { PVC and polyrinyl acetate base with some ABS } \\
\text { plastic added. } \\
\text { Film: Polyethylene terephthalate (PETP) poly- } \\
\text { ester. }\end{array}$ \\
\hline 14 & $\mathrm{~S}-2$ & 0.020 & 20 & $\begin{array}{l}\text { White/green } \\
\text { Smooth }\end{array}$ & Sheet (SR) & $\begin{array}{l}\text { Sides, ceiling, } \\
\text { seat panels }\end{array}$ & Polyvinyl chloride/rinyl acetate $(\sim 89: 11)$ \\
\hline 15 & $\mathrm{~S}-1$ & 4.0 & 110 & $\begin{array}{l}\text { White } \\
\text { Open cell }\end{array}$ & Foam $(F)$ & $\begin{array}{l}\text { Seat cushion } \\
\text { padding }\end{array}$ & Polyether urethane. \\
\hline 16 & $\mathrm{R}-1$ & 0.22 & 44 & $\begin{array}{l}\text { Blue } \\
\text { Loop }\end{array}$ & Rug (t'P) & Flooring & Wool. \\
\hline 17 & $\mathrm{R}-2$ & 0.43 & 83 & $\begin{array}{l}\text { Multi-color } \\
\text { Loop }\end{array}$ & Rug (P) & Flooring & $\begin{array}{l}\text { Pile: Wool. } \\
\text { Back: Polyester. } \\
\text { Pad: Urethane foam. }\end{array}$ \\
\hline 18 & $\mathrm{R}-1$ & 0.22 & 59 & $\begin{array}{l}\text { Black/gray } \\
\text { Loop }\end{array}$ & Rug (UP) & Flooring & Modacrylic/acrylic. \\
\hline 19 & $S-1$ & 0.21 & 9.2 & Green & Pad (F) & Carpet underlay & Polyester urethane foam. \\
\hline 20 & $\mathrm{~L}-3$ & 0.042 & 68 & $\begin{array}{l}\text { Open cell } \\
\text { Gold } \\
\text { Emhossed }\end{array}$ & Laminate $(\mathrm{R})$ & $\begin{array}{l}\text { Panels-Over- } \\
\text { head and } \\
\text { sides }\end{array}$ & $\begin{array}{l}\text { Face: Polyvinyl acetate with trace of ABS } \\
\text { covered with PETP polyester. } \\
\text { Back: Aluminum sheet. }\end{array}$ \\
\hline 21 & $\mathrm{~L}-3$ & 0.044 & 79 & $\begin{array}{l}\text { Tan } \\
\text { Dull, hrushed }\end{array}$ & Laminate $(\mathrm{R})$ & $\begin{array}{l}\text { Panels-Orer- } \\
\text { head and } \\
\text { sides }\end{array}$ & $\begin{array}{l}\text { Face: Vinyl chloride/acrylate copolymer }(80: 20) \text {. } \\
\text { Back: Aluminum sheet. }\end{array}$ \\
\hline 22 & $\mathrm{~L}-1$ & 0.009 & 8.1 & $\begin{array}{l}\text { Aluminum } \\
\text { Matte, shiny }\end{array}$ & Laminate $(F)$ & Window shades & $\begin{array}{l}\text { Face: PETP Polyester. } \\
\text { Back: Tinyl acetate, PTC copolymer. }\end{array}$ \\
\hline
\end{tabular}

$* 1 \mathrm{oz} / \mathrm{yd}^{2}=3.39 \times 10^{\rightarrow} \mathrm{g} / \mathrm{cm}^{2}$. 
Materials Description-Continued

\begin{tabular}{|c|c|c|c|c|c|c|c|}
\hline No. & Code & Thickness & $\begin{array}{l}\text { Unit } \\
\text { weight }\end{array}$ & $\begin{array}{c}\text { Color and } \\
\text { surface }\end{array}$ & Designation & $\begin{array}{c}\text { Present or } \\
\text { intended use }\end{array}$ & Material identification \\
\hline & & Inch & $o z / y d^{2}$ & & & & \\
\hline 23 & $A$ & Irregular & & $\begin{array}{l}\text { White } \\
\text { Smooth }\end{array}$ & $\begin{array}{l}\text { Assembly } \\
\text { (molded) }\end{array}$ & $\begin{array}{l}\text { Assist } \\
\text { handles }\end{array}$ & Polyamide (nylon type). \\
\hline 24 & A & Irregular & & $\begin{array}{l}\text { Green } \\
\text { Smooth }\end{array}$ & $\begin{array}{l}\text { Assembly } \\
\text { (molded) }\end{array}$ & $\begin{array}{l}\text { Seat track } \\
\text { covers }\end{array}$ & Polyvinyl chloride, ABS terpolymer $(94: 6)$. \\
\hline 25 & $\mathrm{~L}-3$ & 0.035 & 39 & $\begin{array}{l}\text { Gray } \\
\text { Glossy }\end{array}$ & Laminate $(\mathbf{R})$ & Galley area & $\begin{array}{l}\text { Face: Melamine formaldehyde. } \\
\text { Back: Urea formaldehyde. }\end{array}$ \\
\hline 26 & $\mathrm{~L}-3$ & 0.032 & 35 & $\begin{array}{l}\text { Blue } \\
\text { Glossy }\end{array}$ & Laminate $(\mathrm{R})$ & Galley area & $\begin{array}{l}\text { Face: Melamine formaldehyde. } \\
\text { Back: Urea formaldehyde. }\end{array}$ \\
\hline 27 & $\mathrm{~S}-2$ & Irregular & & White & Sheet (SR) & $\begin{array}{l}\text { Passenger serv- } \\
\text { ice units }\end{array}$ & $\begin{array}{l}\text { Rigid part: ABS }(40: 40: 20) \text { possible PVC. } \\
\text { Flex part: } \begin{array}{l}\text { Plasticized PVC possible some vinyl } \\
\text { acetate. }\end{array}\end{array}$ \\
\hline 28 & F-1 & 0.028 & 8.0 & $\underset{\text { trace }}{\text { Tan/gold }}$ & Fabric (UC) & Drapery & Modacrylic. \\
\hline 29 & F-1 & 0.030 & 9.3 & $\begin{array}{l}\text { Turquoise, } \\
\text { gold trace }\end{array}$ & Fabric (UC) & Drapery & Modacrylic. \\
\hline 30 & A & 0.41 & 62 & $\begin{array}{l}\text { Tan } \\
\text { Matte }\end{array}$ & $\begin{array}{l}\text { Assembly } \\
\text { (honeycomb) }\end{array}$ & $\begin{array}{l}\text { Ceilings, } \\
\text { bulkheads }\end{array}$ & $\begin{array}{l}\text { Face: Coated glass fabric (Polyester or cross- } \\
\text { linked Acrylic). } \\
\text { Core: Paper honeycomb. } \\
\text { Back: Plastic-impregnated glass fabric }\end{array}$ \\
\hline 31 & $\mathrm{~S}-1$ & 0.010 & 9.6 & $\begin{array}{l}\text { White } \\
\text { Matte }\end{array}$ & Sheet $(\mathbf{F})$ & $\begin{array}{l}\text { Lowered } \\
\text { ceilings }\end{array}$ & $\begin{array}{l}\text { Vinyl chloride/acrylate, possible Polyvinyl } \\
\text { acetate. }\end{array}$ \\
\hline 32 & $\mathrm{~L}-3$ & 0.045 & 75 & $\begin{array}{l}\text { Light blue } \\
\text { Matte }\end{array}$ & Laminate $(\mathbf{R})$ & $\begin{array}{l}\text { Lowered } \\
\text { ceilings }\end{array}$ & $\begin{array}{l}\text { Vinyl chloride/acrylate copolymer film on } \\
\text { aluminum sheet. }\end{array}$ \\
\hline 33 & $\mathrm{~S}-3$ & 0.093 & 91 & $\begin{array}{l}\text { White } \\
\text { Matte }\end{array}$ & Sheet $(\mathbf{R})$ & Hatrack & ABS $(40: 40: 20)$, possible PVC. \\
\hline 34 & $\mathrm{~F}-2$ & 0.010 & 10 & $\begin{array}{l}\text { Tan } \\
\text { Smooth }\end{array}$ & Fabric (C) & $\begin{array}{l}\text { Underside hat- } \\
\text { rack bullnose }\end{array}$ & $\begin{array}{l}\text { Vinyl chloride/Acrylate copolymer on glass } \\
\text { fabric }(28 \%) \text { plus pigment }(13 \%) .\end{array}$ \\
\hline 35 & $\mathrm{~S}-3$ & 0.095 & 90 & $\begin{array}{l}\text { Gray } \\
\text { Dull }\end{array}$ & Sheet $(\mathrm{R})$ & $\begin{array}{l}\text { Toilet floor } \\
\text { pans }\end{array}$ & ABS (40: 40: 20), possible PVC. \\
\hline 36 & $A$ & 0.063 & & $\begin{array}{l}\text { Tan } \\
\text { Smooth }\end{array}$ & $\begin{array}{l}\text { A ssembly } \\
\text { (molded) }\end{array}$ & $\begin{array}{l}\text { Ceiling panel } \\
\text { joint }\end{array}$ & $\begin{array}{l}\text { Plasticized PVC. } \\
\text { Plasticized di-( } 2 \text { ethyl-hexyl) phthalate. }\end{array}$ \\
\hline 37 & $\mathrm{~S}-3$ & 0.097 & 92 & $\begin{array}{l}\text { White } \\
\text { Matte }\end{array}$ & Sheet $(\mathbf{R})$ & Magazine rack & ABS $(40: 40: 20) /$ PVC. \\
\hline 38 & $\mathrm{~S}-3$ & 0.063 & 53 & $\begin{array}{l}\text { Clear } \\
\text { Polished }\end{array}$ & Sheet $(\mathrm{R})$ & Window pane & $\begin{array}{l}\text { Methyl methacrylate/Methyl acrylate copolymer } \\
(90: 10) \text {. }\end{array}$ \\
\hline 39 & $\mathrm{~S}-3$ & 0.064 & 62 & $\begin{array}{l}\text { Tan } \\
\text { Matte }\end{array}$ & Sheet (R) & Control panel & ABS $(40 \%: 40 \%: 20 \%)$, possible PVC. \\
\hline 40 & $\mathrm{~S}-1$ & 0.002 & 1.3 & $\begin{array}{l}\text { Clear } \\
\text { Smooth }\end{array}$ & Film $(\mathbf{F})$ & $\begin{array}{l}\text { Protective } \\
\text { coating }\end{array}$ & Polyvinyl fluoride. \\
\hline 41 & $\mathbf{A}$ & 0.35 & 95 & $\operatorname{Tan}$ & $\begin{array}{l}\text { Assembly } \\
\text { (molded) }\end{array}$ & Bullnose & $\begin{array}{l}\text { Face: ABS. } \\
\text { Back: Polyether urethane foam. }\end{array}$ \\
\hline 42 & $A$ & 1.3 & 35 & $\begin{array}{l}\text { Yellow } \\
\text { Fibrous }\end{array}$ & Pad & Insulation & Glass fiber (plus organic binder). \\
\hline 43 & A & 2.5 & 150 & $\begin{array}{l}\text { Yellow } \\
\text { Fibrous }\end{array}$ & Assembly & Insulation & Glass fiber with lead sheet. \\
\hline 44 & $\mathrm{~S}-1$ & 0.046 & 44 & $\begin{array}{l}\text { Tan } \\
\text { Matte }\end{array}$ & Sheet (F) & Seat panels & PVA/ABS, china clay pigmented, possible PVC. \\
\hline 45 & $\mathrm{~S}-3$ & 0.063 & 60 & $\begin{array}{l}\text { Tan } \\
\text { Matte }\end{array}$ & Sheet $(\mathrm{R})$ & Seat panels & PVC/ABS. \\
\hline 46 & $\mathrm{~S}-3$ & 0.057 & 55 & $\begin{array}{l}\text { White } \\
\text { Matte }\end{array}$ & Sheet (R) & Seat panels & PVC/PMMA (90: 10). \\
\hline 47 & $\mathrm{~F}-1$ & 0.012 & 4.0 & $\begin{array}{l}\text { White } \\
\text { Matte }\end{array}$ & Fabric (UC) & $\begin{array}{l}\text { Lining for seat } \\
\text { pads }\end{array}$ & Cotton. \\
\hline 48 & A & 0.57 & 82 & $\begin{array}{l}\text { Tan } \\
\text { Matte }\end{array}$ & Assembly & Seat panels & $\begin{array}{l}\text { Face: PVC/ABS. } \\
\text { Back: Polyurethane. }\end{array}$ \\
\hline 49 & A & 0.52 & 120 & $\begin{array}{l}\text { White } \\
\text { Matte }\end{array}$ & Assembly & Seat panels & $\begin{array}{l}\text { Face: PVC/PMMA }(90: 10) \\
\text { Back: Urethane foam-polyether type. }\end{array}$ \\
\hline 50 & $\mathrm{~S}-3$ & 0.60 & 35 & $\begin{array}{l}\text { White } \\
\text { Open cell }\end{array}$ & Sheet $(\mathrm{R})$ & $\begin{array}{l}\text { Seat } \\
\text { construction }\end{array}$ & Urethane foam-polyether type. \\
\hline 51 & $S-2$ & 1.0 & 88 & $\begin{array}{l}\text { White } \\
\text { Closed cell }\end{array}$ & Foam (SR) & $\begin{array}{l}\text { Seat } \\
\text { construction }\end{array}$ & $\begin{array}{l}\text { Plasticized foam containing PVC/PVA and } \\
\text { nitrile groups. }\end{array}$ \\
\hline 52 & S-1 & 4.0 & 90 & $\begin{array}{l}\text { White } \\
\text { Open cell }\end{array}$ & $\operatorname{Pad}(\mathrm{F})$ & $\begin{array}{l}\text { Seat } \\
\text { construction }\end{array}$ & Urethane foam-polyether type (FR). \\
\hline 53 & A & 3.0 & 44 & $\begin{array}{l}\text { Tan } \\
\text { Smooth }\end{array}$ & Assembly & Insulation & $\begin{array}{l}\text { Face: Filled rubber on Nylon } 6-6 \text { fabric. } \\
\text { Back: Glass fiber batt. }\end{array}$ \\
\hline
\end{tabular}


Materials Description--Continued

\begin{tabular}{|c|c|c|c|c|c|c|c|}
\hline No. & Code & Thickness & $\begin{array}{c}\text { Unit } \\
\text { weight }\end{array}$ & $\begin{array}{l}\text { Color and } \\
\text { surface }\end{array}$ & Designation & $\begin{array}{l}\text { Present or } \\
\text { intended use }\end{array}$ & Material identification \\
\hline & & Inch & $o z / y d^{2}$ & & & & \\
\hline 54 & A & 1.3 & 28 & $\begin{array}{l}\text { Blue } \\
\text { Smooth }\end{array}$ & Assembly & Insulation & $\begin{array}{l}\text { Face: Organic-filled nylon fabric. } \\
\text { Back: Glass fiber batt. }\end{array}$ \\
\hline 55 & $\mathrm{~F}-2$ & 0.004 & 4.2 & $\begin{array}{l}\text { Tan } \\
\text { Smooth }\end{array}$ & Fabric (C) & $\begin{array}{l}\text { Cover for insu- } \\
\text { lation batt }\end{array}$ & $\begin{array}{l}\text { Polyethylene film over nylon fabric (filled } \\
\text { rubber). }\end{array}$ \\
\hline 56 & $\mathrm{~F}-2$ & 0.004 & 2.9 & $\begin{array}{l}\text { Light blue } \\
\text { Smooth }\end{array}$ & Fabric (C) & $\begin{array}{l}\text { Cover for insu- } \\
\text { lation batt }\end{array}$ & Organic-filled nylon 6-6 fabric. \\
\hline 57 & $\mathrm{~F}-2$ & 0.006 & 6.1 & $\begin{array}{l}\text { Green } \\
\text { Smooth }\end{array}$ & Fabric (C) & $\begin{array}{l}\text { Bulkhead as- } \\
\text { sembly lining }\end{array}$ & Plasticized PVC on Glass fabric. \\
\hline 58 & $\mathrm{~F}-1$ & 0.054 & 14 & $\begin{array}{l}\text { Bluish multi- } \\
\text { colored } \\
\text { weave }\end{array}$ & Fabric (UC) & Drapery & Modacrylic/nylon/cotton. \\
\hline 59 & S-1 & 0.020 & 16 & $\begin{array}{l}\text { White/color } \\
\text { pattern }\end{array}$ & Sheet (F) & Partitions & PVC/PVA (89: 11). \\
\hline 60 & S-3 & 0.060 & 64 & $\begin{array}{l}\text { Gold } \\
\text { Glossy }\end{array}$ & Sheet $(R)$ & Side panels & Plasticized PVC/PVA with ABS. \\
\hline 61 & S-3 & 0.060 & 62 & $\begin{array}{l}\text { Blue } \\
\text { Glossy }\end{array}$ & Sheet $(R)$ & Side panel & PVC/PVA (Small a mount of ABS). \\
\hline 62 & S-3 & 0.069 & 70 & $\begin{array}{l}\text { White with } \\
\text { pattern }\end{array}$ & Sheet $(R)$ & Window panel & Polyvinyl butyral film on PVC/PVA (90: 10). \\
\hline 63 & $\mathrm{~F}-1$ & 0.030 & 9.5 & $\begin{array}{l}\text { Yellow/gold } \\
\text { trace }\end{array}$ & Fabric (UC) & Drapery & Modacrylic/polyester. \\
\hline 64 & $\mathrm{R}-1$ & 0.33 & 64 & $\begin{array}{l}\text { Blue/green } \\
\text { Loop }\end{array}$ & Rug (UP) & Flooring & Modacrylic/acrylic. \\
\hline 65 & $\mathrm{R}-1$ & 0.23 & 41 & $\begin{array}{l}\text { Brown/white/ } \\
\text { black loop }\end{array}$ & Rug (UP) & Flooring & Modacrylic/acrylic. \\
\hline 66 & $\mathrm{~S}-1$ & 0.032 & 25 & $\begin{array}{l}\text { Tan/yellow } \\
\text { Burlap }\end{array}$ & Sheet $(F)$ & Sidewall & Plasticized PVC. \\
\hline 67 & $\mathrm{~L}-2$ & 0.022 & 24 & $\begin{array}{l}\text { White } \\
\text { Burlap }\end{array}$ & Laminate (SR) & Baggage liner & Polyester plastic filled glass fiber fabric. \\
\hline 68 & $\mathrm{~L}-2$ & 0.038 & 34 & $\begin{array}{l}\text { Blue/white/ } \\
\text { yellow } \\
\text { Simulated } \\
\text { fabric }\end{array}$ & Laminate (SR) & $\begin{array}{l}\text { Sidewall, parti- } \\
\text { tion liner }\end{array}$ & $\begin{array}{l}\text { Face: PVC/PVA ( } 89: 11) \\
\text { Back: Cotton fabric and paper }\end{array}$ \\
\hline 69 & $\mathrm{~L}-2$ & 0.026 & 24 & $\begin{array}{l}\text { Blue/white } \\
\text { Simulated } \\
\text { fabric }\end{array}$ & Laminate (SR) & $\begin{array}{l}\text { Sidewall, parti- } \\
\text { tion liner }\end{array}$ & PVC/PVA. \\
\hline 70 & $\mathrm{~L}-2$ & 0.031 & 28 & $\begin{array}{l}\text { Gray } \\
\text { Glossy }\end{array}$ & Laminate (SR) & $\begin{array}{l}\text { Sidewall, parti- } \\
\text { tion liner }\end{array}$ & $\begin{array}{l}\text { Face: Acrylate. } \\
\text { Back: PVC/PVA. }\end{array}$ \\
\hline 71 & $\mathrm{~L}-2$ & 0.033 & 31 & $\begin{array}{l}\text { Tan/white } \\
\text { Embossed }\end{array}$ & Laminate (SR) & $\begin{array}{l}\text { Sidewall, parti- } \\
\text { tion liner }\end{array}$ & PVC/PVA (93: 7). \\
\hline 72 & L-3 & 0.075 & 71 & $\begin{array}{l}\text { Red } \\
\text { Matte }\end{array}$ & Laminate $(\mathrm{R})$ & Door liners & $\begin{array}{l}\text { Face: PVC/PVA. } \\
\text { Back: ABS/PVC. }\end{array}$ \\
\hline 73 & $\mathrm{~S}-3$ & 0.11 & 110 & $\begin{array}{l}\text { Gray } \\
\text { Glossy }\end{array}$ & Sheet $(R)$ & Cockpit liner & ABS/PVC. \\
\hline 74 & S-3 & 0.50 & 440 & $\begin{array}{l}\text { Clear } \\
\text { Glossy }\end{array}$ & Sheet $(R)$ & Window panes & Methyl methacrylate. \\
\hline 75 & F-1 & 0.060 & 19 & $\begin{array}{l}\text { Turquoise } \\
\text { Corrugated }\end{array}$ & Fabric (UC) & Upholstery & Catton/nylon (small amount of polyester). \\
\hline 76 & $A$ & 0.38 & 76 & $\begin{array}{l}\text { White } \\
\text { Smooth }\end{array}$ & $\begin{array}{l}\text { Assembly } \\
\text { (honeycomb) }\end{array}$ & Ceiling panel & $\begin{array}{l}\text { Face: Acrylic/vinyl coating over plywood } \\
\text { (paper). } \\
\text { Core: Paper with cresolformaldehyde resin } \\
\text { adhesive. }\end{array}$ \\
\hline 100 & $S-3$ & 0.18 & 180 & $\begin{array}{l}\text { Clear } \\
\text { Polished }\end{array}$ & Sheet (R) & Window panes & Methyl methacrylate. \\
\hline 101 & F-1 & 0.015 & 4.4 & White & Fabric (UC) & Drapery & Polyamide (aromatic-type). \\
\hline 102 & F-1 & 0.015 & 6.1 & Green & Fabric (UC) & Drapery & Polyamide (aromatic-type). \\
\hline 103 & $S-3$ & 1.0 & 28 & $\begin{array}{l}\text { White } \\
\text { Porous }\end{array}$ & Foam $(\mathrm{R})$ & $\begin{array}{l}\text { Foam } \\
\text { insulation }\end{array}$ & Chlorinated PVC. \\
\hline 104 & $A$ & 1.0 & 42 & $\begin{array}{l}\text { White } \\
\text { Embossed }\end{array}$ & Assembly & $\begin{array}{l}\text { Wall } \\
\text { Insulation }\end{array}$ & $\begin{array}{l}\text { Glass fabric ( } 100 \%) \\
\text { Bonded to glass-fiber batt. }\end{array}$ \\
\hline 105 & F-2 & 0.033 & 26 & $\begin{array}{l}\text { Aluminum } \\
\text { Glossy }\end{array}$ & Fabric (C) & $\begin{array}{l}\text { High tempera- } \\
\text { ture liner }\end{array}$ & Aluminum on asbestos. \\
\hline 106 & $S-3$ & 0.13 & 120 & $\begin{array}{l}\text { Clear } \\
\text { Glossy }\end{array}$ & Sheet $(R)$ & $\begin{array}{l}\text { Window panes } \\
\text { fabricated } \\
\text { parts }\end{array}$ & Poly (diphenylol propane) carbonate. \\
\hline
\end{tabular}


Materials Description-Continued

\begin{tabular}{|c|c|c|c|c|c|c|c|}
\hline No. & Code & Thickness & $\begin{array}{c}\text { Unit } \\
\text { weight }\end{array}$ & $\begin{array}{l}\text { Color and } \\
\text { surface }\end{array}$ & Designation & $\begin{array}{l}\text { Present or } \\
\text { intended use }\end{array}$ & Material identification \\
\hline & & Inch & $o z / y d^{2}$ & & & & \\
\hline 107 & $\mathrm{~F}-1$ & 0.013 & 5.8 & White & Fabric (UC) & Drapery & Modacrylic $(100 \%)$. \\
\hline 108 & F-1 & 0.013 & 5.9 & Orange & Fabric (UC) & Drapery & Modacrylic $(100 \%)$. \\
\hline 109 & $\mathrm{~S}-3$ & 0.080 & 62 & $\begin{array}{l}\text { Yellow } \\
\text { Glossy }\end{array}$ & Sheet $(\mathbf{R})$ & Paneling & Poly (phenylene oxide). \\
\hline 110 & $\mathrm{~S}-3$ & 0.13 & 110 & $\begin{array}{l}\text { Dark gray } \\
\text { Matte }\end{array}$ & Sheet $(\mathrm{R})$ & Paneling & PVC/PMMA plus ABS. \\
\hline 111 & S-3 & 0.060 & 57 & $\begin{array}{l}\text { Green } \\
\text { Matte }\end{array}$ & Sheet $(\mathbf{R})$ & Paneling & PVC/PMMA plus ABS. \\
\hline$\stackrel{112 \mathrm{~A}}{\mathrm{~B}}$ & S-2 & $\begin{array}{l}0.060 \\
0.020\end{array}$ & $\begin{array}{l}54 \\
18\end{array}$ & $\begin{array}{l}\text { Clear } \\
\text { Glossy }\end{array}$ & Sheet (SR) & $\begin{array}{l}\text { Fabricated } \\
\text { parts }\end{array}$ & Polysulfone. \\
\hline 113 & S-1 & 0.30 & 11 & $\begin{array}{l}\text { White } \\
\text { Fluffy }\end{array}$ & $\mathrm{Pad}$ & $\begin{array}{l}\text { Seat padding, } \\
\text { wall } \\
\text { insulation }\end{array}$ & Glass fiber $(100 \%)$. \\
\hline 114 & F-2 & 0.010 & 7.8 & $\begin{array}{l}\text { White } \\
\text { Matte }\end{array}$ & Fabric (C) & Headliner & $\begin{array}{l}\text { Glass fabric coated with acrylic (aromatic } \\
\text { plasticizer). }\end{array}$ \\
\hline 115 & S-1 & 0.0015 & 2.2 & $\begin{array}{l}\text { Clear } \\
\text { Smooth }\end{array}$ & Film (F) & Protec tive cover & Poly (difluorochloroethylene). \\
\hline 116 & S-2 & 0.020 & 17 & $\begin{array}{l}\text { Tan } \\
\text { Smooth }\end{array}$ & Sheet (SR) & Panel sub-strate & Polyamide (aromatic type). \\
\hline 117 & S-3 & 0.045 & 50 & $\begin{array}{l}\text { White } \\
\text { Glossy }\end{array}$ & Sheet $(\mathbf{R})$ & Paneling & PVC/poly(vinylidene chloride). \\
\hline $\begin{array}{r}118 \mathrm{~A} \\
\mathrm{~B} \\
\mathrm{C} \\
\mathrm{D}\end{array}$ & S-1 & $\begin{array}{l}0.002 \\
0.005 \\
0.003 \\
0.005\end{array}$ & $\begin{array}{l}2.1 \\
5.4 \\
3.5 \\
5.9\end{array}$ & $\begin{array}{l}\text { Amber } \\
\text { Clear } \\
\text { Glossy }\end{array}$ & Sheet $(\mathbf{F})$ & $\begin{array}{l}\text { High tempera- } \\
\text { ture insula- } \\
\text { tion }\end{array}$ & Polytetrafluorcethylene films over polyimide. \\
\hline 119 & $\mathrm{~F}-2$ & 0.007 & 5.0 & Blue & Fabric (C) & Headliner & Glass fabric (97\%) with organic finish. \\
\hline 120 & $\mathrm{~S}-2$ & 0.23 & 20 & $\begin{array}{l}\text { Gray } \\
\text { Fibrous }\end{array}$ & $\mathrm{Pad}$ & Insulation & Asbestos fiber. \\
\hline 121 & S-3 & 0.063 & 64 & $\begin{array}{l}\text { Tan } \\
\text { Smooth }\end{array}$ & Sheet $(\mathbf{R})$ & $\begin{array}{l}\text { Panel } \\
\text { substrate }\end{array}$ & Polyamide (aromatic type). \\
\hline 122 & S-3 & 0.11 & 130 & $\begin{array}{l}\text { Gray } \\
\text { Glossy }\end{array}$ & Sheet $(\mathrm{R})$ & Paneling & Polyvinyldichloride. \\
\hline 123 & S-1 & 4.0 & 380 & $\begin{array}{l}\text { Black } \\
\text { Open cell }\end{array}$ & Foam (F) & Seat padding & Chloroprene. \\
\hline 124 & $\mathrm{~F}-1$ & 0.012 & 9.2 & $\begin{array}{l}\text { Maroon } \\
\text { Glossy }\end{array}$ & Fabric (UC) & Wall covering & Plasticized poly(vinylidene chloride). \\
\hline 125 & F-2 & 0.005 & 4.0 & $\begin{array}{l}\text { Light green } \\
\text { Glossy }\end{array}$ & Fabric (C) & Headliner & Glass fabric $(97 \%)$ with organic finish. \\
\hline 126 & F-2 & 0.006 & 4.2 & $\begin{array}{l}\text { Light gray } \\
\text { Glossy }\end{array}$ & Fabric (C) & Headliner & Glass fabric $(83 \%)$ with organic finish. \\
\hline 127 & S-2 & 0.034 & 29 & $\begin{array}{l}\text { Blue } \\
\text { Matte }\end{array}$ & Sheet (SR) & Paneling & $\begin{array}{l}\text { Face: Plasticized PVC/PVA (90:10). } \\
\text { Back: Polyamide (Aromatic type). }\end{array}$ \\
\hline $128 \mathrm{~A}$ & S-1 & 4.0 & 89 & $\begin{array}{l}\text { White } \\
\text { Open cell }\end{array}$ & Foam $(\mathrm{F})$ & Seat padding & Polyether urethane (FR). \\
\hline B & & 4.0 & 67 & $\begin{array}{l}\text { White } \\
\text { Open cell }\end{array}$ & & & Polyether urethane. \\
\hline 129 & S-1 & 0.071 & 99 & $\begin{array}{l}\text { Black } \\
\text { Smooth }\end{array}$ & Sheet $(\mathbf{F})$ & $\begin{array}{l}\text { Elastomer, } \\
\text { seals }\end{array}$ & $\begin{array}{l}\text { Copolymer of tetrafluoro-ethylene/vinylidene } \\
\text { fluoride. }\end{array}$ \\
\hline 130 & S-1 & 0.067 & 83 & $\begin{array}{l}\text { Tan } \\
\text { Smooth }\end{array}$ & Sheet $(\mathrm{F})$ & $\begin{array}{l}\text { Elastomer, } \\
\text { gaskets }\end{array}$ & Chlorosulfonated polyethylene. \\
\hline 131 & S-1 & 0.065 & 82 & $\begin{array}{l}\text { Black } \\
\text { Smooth }\end{array}$ & Sheet $(\mathrm{F})$ & $\begin{array}{l}\text { Elastomer, } \\
\text { hoses }\end{array}$ & Chloroprene. \\
\hline 132 & F-1 & 0.028 & 8.7 & Green & Fabric (UC) & Drapery & Modacrylic and metallized fiber $(94: 6)$. \\
\hline 133 & $\mathrm{~L}-1$ & 0.040 & 36 & $\begin{array}{l}\text { Copper } \\
\text { Glossy }\end{array}$ & Laminate (F) & Dado paneling & $\begin{array}{l}\text { Face: Plasticized PVC/PVA. } \\
\text { Back: Polyamide (aromatic type) paper. }\end{array}$ \\
\hline 134 & $\mathrm{~L}-1$ & 0.032 & 27 & $\begin{array}{l}\text { Light tan } \\
\text { Glossy }\end{array}$ & Laminate (F) & Hatrack & $\begin{array}{l}\text { Face: Plasticized PVC/PVA and cotton fiber. } \\
\text { Back: Polyamide (aromatic type) paper. }\end{array}$ \\
\hline 135 & $\mathrm{~L}-2$ & 0.029 & 26 & $\begin{array}{l}\text { Blue/white } \\
\text { pattern } \\
\text { Smooth }\end{array}$ & Laminate (SR) & $\begin{array}{l}\text { Paneling, } \\
\text { Bulkhead } \\
\text { dividers }\end{array}$ & $\begin{array}{l}\text { Face: PVC/PVA (90: } 10 \text { ) } \\
\text { Back: Polyamide (aromatic type) paper. }\end{array}$ \\
\hline 136 & $\mathbf{L}-3$ & 0.099 & 84 & $\begin{array}{l}\text { Lt. gray/gold } \\
\text { pattern } \\
\text { Rough }\end{array}$ & Laminate (R) & Flooring & $\begin{array}{l}\text { Plasticized PVC/PVA. } \\
\text { Top coating-mostly plasticized. }\end{array}$ \\
\hline 137 & $\mathrm{~L}-3$ & 0.074 & 72 & $\begin{array}{l}\text { Clear/white/ } \\
\text { blue } \\
\text { Smooth }\end{array}$ & Laminate (R) & $\begin{array}{l}\text { Window reveals, } \\
\text { dado } \\
\text { Seat backs }\end{array}$ & $\begin{array}{l}\text { Plasticized PVC/PVA (90:10) over pigmented } \\
\text { ABS, asbestos-filled. }\end{array}$ \\
\hline
\end{tabular}


Materials Description-Continued

\begin{tabular}{|c|c|c|c|c|c|c|c|}
\hline No. & Code & Thickness & $\begin{array}{l}\text { Unit } \\
\text { weight }\end{array}$ & $\begin{array}{l}\text { Color and } \\
\text { surface }\end{array}$ & Designation & $\begin{array}{l}\text { Presert or } \\
\text { intended use }\end{array}$ & Material identification \\
\hline & & Inch & $o z / y d^{2}$ & & & & \\
\hline 138 & F-1 & 0.015 & 5.8 & $\begin{array}{l}\text { Green } \\
\text { Smooth }\end{array}$ & Fabric (UC) & Drapery (FR) & Polyamide (aromatic type) cotton $(50 \%: 50 \%)$. \\
\hline 139 & $\mathbf{F}-2$ & 0.007 & 6.6 & $\begin{array}{l}\text { White } \\
\text { Smooth }\end{array}$ & Fabric (C) & $\begin{array}{l}\text { Headliner, } \\
\text { baggage liner }\end{array}$ & $\begin{array}{l}\text { Glass fabric }(60 \%) \text { coated with polyvinylidene } \\
\text { fluoride. }\end{array}$ \\
\hline 140 & F-1 & 0.024 & 12 & $\begin{array}{l}\text { White/blue } \\
\text { Smooth }\end{array}$ & Fabric (UC) & $\begin{array}{l}\text { Matress } \\
\text { ticking (FR) }\end{array}$ & Cotton. \\
\hline 141 & $\mathrm{~S}-2$ & 0.031 & 28 & $\begin{array}{l}\text { Cream } \\
\text { semi-clear } \\
\text { Glossy }\end{array}$ & Sheet (SR) & $\begin{array}{l}\text { Fabricated } \\
\text { parts }(\mathrm{FR})\end{array}$ & Polysulf one. \\
\hline 142 & S-3 & 1.0 & 12 & $\begin{array}{l}\text { White } \\
\text { Fine grain }\end{array}$ & Foam $(\mathrm{R})$ & Insulation & (Urea formaldehyde). \\
\hline 143 & $\mathrm{R}-1$ & 0.30 & 45 & $\begin{array}{l}\text { Green } \\
\text { Loop }\end{array}$ & Rug (UP) & Flooring & Polyamide (Aromatic type). \\
\hline 144 & $\mathrm{~F}-1$ & 0.035 & 11 & $\begin{array}{l}\text { Green/wbite/ } \\
\text { orange }\end{array}$ & Fabric (UC) & Upholstery & Polyamide (Aromatic type). \\
\hline 145 & F-2 & 0.031 & 18 & $\begin{array}{l}\text { Silver } \\
\text { Reflective }\end{array}$ & Fabric $(\mathrm{C})$ & $\begin{array}{l}\text { Insulation, } \\
\text { baggage liner }\end{array}$ & Aluminum/polyester film on asbestos fabric. \\
\hline 146 & $\mathbf{F}-1$ & 0.035 & 9.9 & White & Fabric (UC) & $\begin{array}{l}\text { Upholstery, } \\
\text { drapery }\end{array}$ & $\begin{array}{l}\text { Polyamide (more Aromatic groups than } 14 \\
\text { and 144). }\end{array}$ \\
\hline 147 & $\mathrm{~S}-3$ & 0.23 & 210 & $\begin{array}{l}\text { Clear } \\
\text { Glossy }\end{array}$ & Sheet $(R)$ & $\begin{array}{l}\text { Window panes, } \\
\text { fabricated } \\
\text { parts }\end{array}$ & Poly metbyl methacrylate. \\
\hline 148 & $\mathrm{R}-1$ & 0.25 & 56 & $\begin{array}{l}\text { (A) Blue } \\
\text { (B) Brown } \\
\text { (C) Green } \\
\text { Loop }\end{array}$ & Rug (UP) & Flooring & Pile: Modacrvlic (100\%). \\
\hline 149 & F-1 & 0.15 & 10 & $\begin{array}{l}\text { Cream } \\
\text { Fluffy }\end{array}$ & Fabric (UC) & Blanket & Modacrylic $(100 \%)$ \\
\hline 150 & $\mathrm{~S}-1$ & 4.0 & 89 & $\begin{array}{l}\text { White } \\
\text { Open cell }\end{array}$ & Foam $(F)$ & $\begin{array}{l}\text { Seat padding } \\
\quad\left(\mathrm{F}^{\prime} \mathrm{R}\right)\end{array}$ & Polyether urethane. \\
\hline 151 & $\mathbf{L}-3$ & 0.054 & 75 & $\begin{array}{l}\text { Light tan } \\
\text { Matte }\end{array}$ & Laminate $(\mathrm{R})$ & Paneling & Plasticized PVC/PVA on aluminum sheet. \\
\hline 152 & $\mathbf{L}-2$ & 0.057 & 52 & $\begin{array}{l}\text { Light blue } \\
\text { Matte }\end{array}$ & Laminate (SR) & Paneling & $\begin{array}{l}\text { Face (blue): PVC/PVA }(89: 11) \\
\text { Back (tan): PVC/PMMA }(90: 10)\end{array}$ \\
\hline 153 & $\mathrm{~F}-1$ & 0.033 & 6.8 & $\begin{array}{l}\text { White } \\
\text { Open weave }\end{array}$ & Fabric (UC) & $\begin{array}{l}\text { Casement } \\
\text { drapery }\end{array}$ & $\begin{array}{l}\text { Modacrylic/rayon/poly(vinylidene cbloride) } \\
20 \% \text {. }\end{array}$ \\
\hline 154 & $\mathrm{~S}-1$ & 0.11 & 63 & $\begin{array}{l}\text { Red } \\
\text { Closed cell }\end{array}$ & Sbeet $(\mathbf{F})$ & Padding & Silicone rubber. \\
\hline 155 & $\mathrm{~s}-3$ & 0.060 & 53 & $\begin{array}{l}\text { Clear } \\
\text { Glossy }\end{array}$ & Sheet $(\mathrm{R})$ & $\begin{array}{l}\text { Window panes } \\
\text { Fabricated parts }\end{array}$ & Polycarbonate. \\
\hline 156 & $\mathrm{~F}-2$ & 0.007 & 6.3 & $\begin{array}{l}\text { White } \\
\text { Smooth }\end{array}$ & Fabric (C) & Headliner & $\begin{array}{l}\text { Poly (vinylidene fluoride) coating, on Polyamid } \\
\text { (aromatic type) fabric. }\end{array}$ \\
\hline 157 & $\mathrm{~F}-1$ & 0.035 & 10 & White & Fabric (UC) & Drapery & Modacrylic $(100 \%)$ \\
\hline 158 & $\mathrm{~S}-2$ & 0.028 & 29 & $\begin{array}{l}\text { Cream } \\
\text { Glossy }\end{array}$ & Sheet (SR) & $\begin{array}{l}\text { Panels, fabri- } \\
\text { cated parts }\end{array}$ & PVC/ABS (94:6). \\
\hline 159 & $\mathrm{~S}-2$ & 0.034 & 34 & $\begin{array}{l}\text { Olive } \\
\text { Glossy }\end{array}$ & Sheet (SR) & $\begin{array}{l}\text { Panels, fabri- } \\
\text { cated parts }\end{array}$ & PVC/acrylic (90: 10$)$ \\
\hline 160 & $\mathrm{~S}-3$ & 0.055 & 65 & $\begin{array}{l}\text { White } \\
\text { Glossy }\end{array}$ & Sheet $(\mathrm{R})$ & $\begin{array}{l}\text { Panels, fabri- } \\
\text { cated parts }\end{array}$ & $\begin{array}{l}\text { Styrene/polyester, fiberglass-reinforced }(25 \%) \\
\mathrm{TiO}_{2} \text { pigment. }\end{array}$ \\
\hline 161 & $\mathbf{L}-3$ & 0.032 & 57 & $\begin{array}{l}\text { Wood grain } \\
\text { pattern } \\
\text { Smooth }\end{array}$ & Laminate $(\mathrm{R})$ & $\begin{array}{l}\text { Panels, interior } \\
\text { finish }\end{array}$ & PVC/acrylic on aluminum sheet. \\
\hline 162 & $\mathrm{~F}-1$ & 0.020 & 13 & White & Fabric (UC) & $\begin{array}{l}\text { High-tempera- } \\
\text { ture insula- } \\
\text { tion fabric }\end{array}$ & Asbestos/glass/polyamide (aromatic type). \\
\hline 163 & $\mathbf{L}-2$ & 0.031 & 39 & $\begin{array}{l}\text { Wood grain } \\
\text { pattern } \\
\text { Smootb }\end{array}$ & Laminate (SR) & $\begin{array}{l}\text { Panels, interior } \\
\text { finish }\end{array}$ & PVC/PVA (95:5) on filled asbestos $(71 \%)$ \\
\hline 164 & S-3 & 0.070 & 60 & $\begin{array}{l}\text { White } \\
\text { Glossy }\end{array}$ & Sheet $(R)$ & $\begin{array}{l}\text { Fabricated } \\
\text { parts }\end{array}$ & ABS. \\
\hline
\end{tabular}


Appendix 3 .

Summary of Test Results; Smoke and Gas Concentration

\begin{tabular}{|c|c|c|c|c|c|c|c|c|c|c|c|c|c|c|c|}
\hline \multirow{3}{*}{$\begin{array}{l}\text { Sample } \\
\text { number }\end{array}$} & \multirow{3}{*}{$\begin{array}{l}\text { Specimen } \\
\text { weight }\end{array}$} & \multirow{3}{*}{$\begin{array}{c}\text { Test } \\
\text { Exposure } \\
F=\text { Flaming } \\
N=\text { Nonflaming }\end{array}$} & \multicolumn{6}{|c|}{ Smoke } & \multirow{2}{*}{\multicolumn{7}{|c|}{$\frac{\text { Gas coneentration }}{\text { Maximum indication, Colorimetric tube }}$}} \\
\hline & & & \multirow{2}{*}{\multicolumn{2}{|c|}{$\begin{array}{c}\text { Maximum } \\
\text { specific optical } \\
\text { density } \\
D_{m}\end{array}$}} & \multirow{2}{*}{\multicolumn{2}{|c|}{$\begin{array}{l}\text { Maximum } \\
\text { rate } \\
R_{m}\end{array}$}} & \multirow{2}{*}{\multicolumn{2}{|c|}{$\begin{array}{l}\text { Time to } \\
D_{s}=16 \\
t_{c}\end{array}$}} & & & & & & & \\
\hline & & & & & & & & & $\mathrm{CO}$ & & $\mathrm{HC}$ & $\mathrm{Cl}$ & & & Others \\
\hline 1 & $\begin{array}{l}g \\
2.2\end{array}$ & $\stackrel{F}{N}$ & 14 & 60 & $2^{m i}$ & 19 & $\mathrm{NR}^{\min }$ & 1.2 & $50^{p p m}$ & $\begin{array}{l}n \\
\quad 30\end{array}$ & $0^{p p i}$ & $m$ & $6^{p l}$ & 5 & $p p m$ \\
\hline 2 & 1.8 & $\stackrel{F}{N}$ & 72 & 50 & 29 & 24 & 0.5 & 0.7 & 200 & 45 & $200 \mathrm{~S}$ & $150 \mathrm{~S}$ & 45 & 35 & \\
\hline 3 & 2.8 & $\stackrel{F}{N}$ & 60 & 89 & 20 & 35 & 1.0 & 0.9 & 80 & 20 & 40 & 25 & 15 & 10 & \\
\hline 4 & s 2.6 & $\stackrel{F}{N}$ & 16 & 6 & 4 & $<1$ & 15.0 & $\mathrm{NR}$ & 30 & 70 & 0 & 0 & 0 & 0 & \\
\hline 5 & 4.4 & $\stackrel{F}{N}$ & 193 & 191 & 185 & 30 & 0.3 & 1.4 & 270 & 80 & $150 \mathrm{~S}$ & $150 \mathrm{~s}$ & 0 & 0 & \\
\hline 6 & 5.0 & $\stackrel{F}{N}$ & 204 & 272 & 163 & 28 & 0.3 & 1.5 & 350 & 400 & $200 \mathrm{~S}$ & $300 \mathrm{~s}$ & 3 & 2 & \\
\hline 7 & 12.2 & $\stackrel{F}{N}$ & 439 & 375 & 200 & 140 & 0.8 & 1.2 & 500 & 125 & 90 & 30 & 20 & 30 & \\
\hline 8 & 7.0 & $\stackrel{F}{N}$ & 96 & 418 & 50 & 60 & 1.8 & 2.0 & 140 & 800 & 0 & 0 & 2 & 2 & \\
\hline 9 & 9.1 & $\stackrel{F}{N}$ & 380 & 276 & 178 & 67 & 0.5 & 1.2 & 500 & 180 & $300 \mathrm{~S}$ & $80 \mathrm{~s}$ & 20 & 12 & \\
\hline 10 & 7.1 & $\stackrel{F}{N}$ & $>660$ & 76 & 340 & 6 & 0.6 & 4.3 & 260 & 25 & 0 & 0 & 10 & 8 & $\mathrm{NO}+\mathrm{NO}_{2}: 30$ \\
\hline 11 & 11.8 & $\stackrel{F}{N}$ & $>660$ & 167 & 280 & 8 & 0.7 & 3.5 & 360 & 40 & 0 & 0 & 10 & 9 & \\
\hline 12 & 15.1 & $\stackrel{F}{N}$ & 229 & 107 & 61 & 17 & 1.0 & 3.0 & 550 & 600 & $1200 \mathrm{~S}$ & $800 \mathrm{~S}$ & 0 & 0 & \\
\hline 13 & 5.4 & $\stackrel{F}{N}$ & 289 & 55 & 120 & 4 & 0.6 & 6.5 & 200 & 60 & $300 \mathrm{~S}$ & $250 \mathrm{~s}$ & 3 & 2 & \\
\hline 14 & 4.0 & $\stackrel{F}{N}$ & 139 & 20 & 96 & 4 & 0.6 & 3.8 & 120 & 60 & $300 \mathrm{~S}$ & $250 \mathrm{~S}$ & 0 & 0 & \\
\hline 15 & $\mathrm{~b}_{2.6}$ & $\stackrel{F}{N}$ & 35 & 156 & 6 & 9 & 1.4 & 0.5 & 50 & 50 & 0 & 0 & 2 & 2 & \\
\hline 16 & 9.4 & $\stackrel{F}{N}$ & 123 & 87 & 23 & 6 & 1.6 & 2.1 & 190 & 90 & 0 & 0 & 15 & 20 & \\
\hline 17 & 15.2 & $\stackrel{F}{N}$ & 129 & 206 & 50 & 40 & 2.2 & 2.0 & 320 & 300 & 0 & 0 & 15 & 60 & $\mathrm{NO}+\mathrm{NO}_{2}: 25$ \\
\hline 18 & 11.6 & $F_{N}^{\prime}$ & 350 & 312 & 170 & 59 & 1.2 & 2.1 & 270 & 240 & 30 & 6 & 8 & 50 & \\
\hline 19 & 1.7 & $\stackrel{F}{N}$ & 58 & 77 & 10 & 13 & 1.9 & 0.6 & 150 & 45 & 0 & 0 & 2 & 0 & \\
\hline 20 & 13.0 & $\stackrel{F}{N}$ & 76 & 22 & 14 & 2 & 5.2 & 21.6 & 210 & 20 & 100 & 80 & 2 & 0 & \\
\hline 21 & 14.9 & $\stackrel{F}{N}$ & 81 & 82 & 26 & 17 & 2.1 & 5.0 & 230 & 30 & 200 & 100 & 0 & 0 & \\
\hline 22 & 1.3 & $\stackrel{F}{N}$ & 28 & 24 & 4 & 4 & 1.5 & 5.7 & 90 & 10 & 70 & 30 & 0 & 0 & \\
\hline 23 & a 50.0 & $\stackrel{F}{N}$ & 162 & 105 & 11 & 3 & 5.6 & 13.6 & 500 & 30 & 0 & 0 & 65 & 2 & $\mathrm{NO}+\mathrm{NO}_{2}: 50$ \\
\hline 24 & 11.4 & $\stackrel{F}{N}$ & 454 & 167 & 160 & 40 & 0.7 & 1.8 & 550 & 60 & $1300 \mathrm{~s}$ & $1000 \mathrm{~S}$ & 4 & 1 & \\
\hline 25 & 7.2 & $\stackrel{F}{N}$ & 94 & 44 & 9 & 6 & 3.5 & 4.5 & 320 & 80 & 0 & 0 & 10 & 4 & \\
\hline 26 & 6.7 & $\stackrel{F}{N}$ & 50 & 43 & 4 & 6 & 3.7 & 3.6 & 300 & 130 & 0 & 0 & 8 & 7 & \\
\hline 27 & 4.6 & $\stackrel{F}{N}$ & $>660$ & 126 & 260 & 5 & 0.8 & 5.3 & 700 & 50 & 50 & 20 & 25 & 8 & \\
\hline 28 & 1.5 & $\stackrel{F}{N}$ & 76 & 48 & 23 & 20 & 0.4 & 0.8 & 170 & 60 & 150 & 150 & 60 & 50 & \\
\hline 29 & 1.6 & $\stackrel{F}{N}$ & 66 & 52 & 23 & 17 & 0.5 & 0.9 & 200 & 40 & 150 & 200 & 60 & 40 & \\
\hline
\end{tabular}

See footnote at the end of table. 


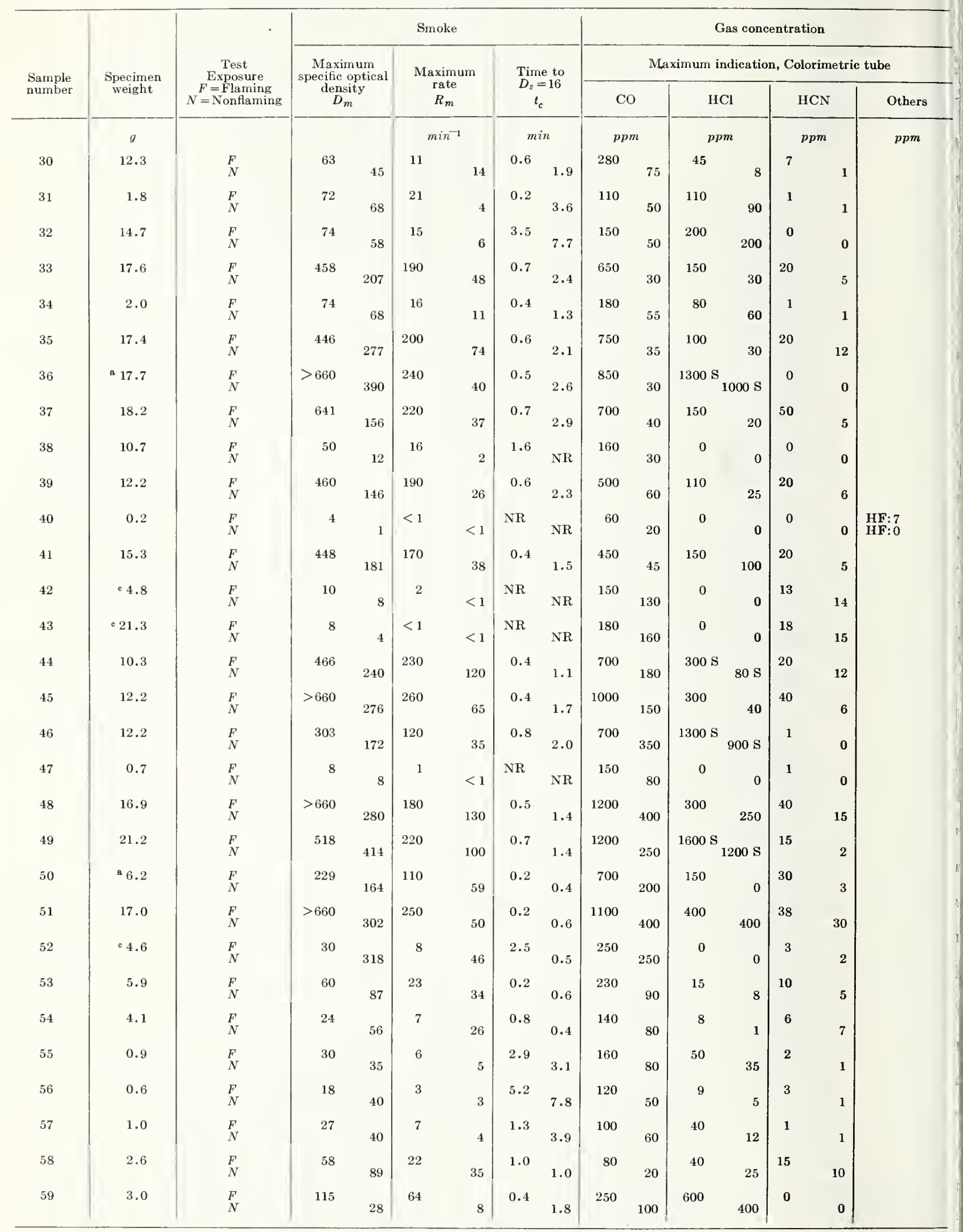


Summary of Test Results; Smoke and Gas Concentration-Continued

\begin{tabular}{|c|c|c|c|c|c|c|c|c|c|c|c|c|c|c|c|}
\hline \multirow{3}{*}{$\begin{array}{l}\text { Sample } \\
\text { number }\end{array}$} & \multirow{3}{*}{$\begin{array}{c}\text { Specimen } \\
\text { weight }\end{array}$} & \multirow{3}{*}{$\begin{array}{c}\text { Test } \\
\text { Exposure } \\
F=\text { Flaming } \\
N=\text { Nonflaming } \\
\end{array}$} & \multicolumn{6}{|c|}{ Smoke } & \multicolumn{7}{|c|}{ Gas concentration } \\
\hline & & & \multirow{2}{*}{\multicolumn{2}{|c|}{$\begin{array}{c}\text { Maximum } \\
\text { specific optical } \\
\text { density } \\
D_{m} \\
\end{array}$}} & \multirow{2}{*}{\multicolumn{2}{|c|}{$\begin{array}{c}\text { Maximum } \\
\text { rate } \\
R_{m}\end{array}$}} & \multirow{2}{*}{\multicolumn{2}{|c|}{$\begin{array}{c}\text { Time to } \\
D_{s}=16 \\
t_{c}\end{array}$}} & \multicolumn{7}{|c|}{ Maximum indication, Colorimetric tube } \\
\hline & & & & & & & & & $\mathrm{Cc}$ & & $\mathrm{HCl}$ & & & $\mathrm{ICN}$ & Others \\
\hline & $g$ & & & & & & $m i$ & & $p p$ & & $p p m$ & & & $p m$ & $p p m$ \\
\hline 60 & 12.8 & $\stackrel{F}{N}$ & 609 & 290 & 260 & 47 & & 1.2 & 1100 & 150 & $1500 \mathrm{~S}_{8}$ & $800 \mathrm{~S}$ & 15 & 4 & \\
\hline 61 & 12.7 & $\stackrel{F}{N}$ & 600 & 267 & 250 & 77 & 0.5 & 1.4 & 1000 & 130 & $1400 \mathrm{~s}_{8}$ & $850 \mathrm{~s}$ & 25 & 8 & \\
\hline 62 & 13.2 & $\stackrel{F}{N}$ & 436 & 216 & 180 & 33 & 0.5 & 1.6 & 800 & 320 & $700 \mathrm{~S}_{4}$ & $450 \mathrm{~s}$ & 20 & 5 & \\
\hline 63 & 2.0 & $\stackrel{F}{N}$ & 60 & 78 & 20 & 22 & 0.5 & 0.7 & 280 & 80 & 150 & 100 & 45 & 40 & \\
\hline 64 & 12.1 & $\stackrel{F}{N}$ & 295 & 254 & 140 & 92 & 0.6 & 1.3 & 380 & 160 & 30 & 0 & 25 & $55 \mathrm{~d}$ & \\
\hline 65 & 8.3 & $\stackrel{F}{N}$ & 355 & 327 & 310 & 86 & 0.7 & 2.0 & 300 & 170 & 0 & 0 & 17 & $110 \mathrm{~d}$ & \\
\hline 66 & 5.0 & $\stackrel{F}{N}$ & 199 & 180 & 180 & 44 & 0.4 & 1.4 & 420 & 500 & 450 & 450 & 0 & 1 & \\
\hline 67 & 4.7 & $\stackrel{F}{N}$ & 69 & 60 & 28 & 6 & 0.4 & 4.2 & 230 & 30 & 20 & 8 & 0 & 0 & \\
\hline 68 & 6.7 & $\stackrel{F}{N}$ & 311 & 246 & 160 & 19 & 0.6 & 2.4 & 500 & 200 & $800 \mathrm{~S}$ & 200 & 0 & 0 & \\
\hline 69 & 5.3 & $\underset{N}{F}$ & 234 & 178 & 200 & 33 & 0.4 & 1.2 & 500 & 190 & $800 \mathrm{~S}$ & 500 & 0 & 0 & \\
\hline 70 & 5.5 & $\stackrel{F}{N}$ & 295 & 178 & 250 & 26 & 0.4 & 1.2 & 450 & 150 & $700 \mathrm{~s}$ & 300 & 1 & 1 & \\
\hline 71 & 6.0 & $\stackrel{F}{N}$ & 300 & 104 & 230 & 25 & 0.4 & 1.0 & 450 & 280 & $1100 \mathrm{~S}$ & 350 & 1 & 1 & \\
\hline 72 & 14.1 & $\stackrel{F}{N}$ & $>660$ & 286 & 260 & 45 & 0.6 & 1.6 & 1200 & 130 & $800 \mathrm{~s}$ & 400 & 17 & 7 & \\
\hline 73 & 20.8 & $\stackrel{F}{N}$ & 574 & 442 & 180 & 58 & 0.6 & 2.0 & 1300 & 200 & 400 & 200 & 40 & 20 & \\
\hline 74 & 86.9 & $\stackrel{F}{N}$ & & 328 & & 5 & & 9.0 & & 140 & & 0 & & 0 & \\
\hline 75 & 3.9 & $\stackrel{F}{N}$ & 39 & 175 & 13 & 29 & 0.9 & 1.2 & 180 & 120 & 0 & 0 & 5 & 5 & \\
\hline 76 & 16.0 & $\stackrel{F}{N}$ & 151 & 200 & 35 & 70 & 1.2 & 1.4 & 220 & 100 & 80 & 5 & 7 & 3 & \\
\hline 100 & 32.9 & $\stackrel{F}{N}$ & 383 & 203 & 120 & 12 & 1.9 & 6.0 & 2200 & 400 & 100 & 8 & 0 & 0 & \\
\hline 101 & 0.9 & $\stackrel{F}{N}$ & 10 & 0 & $<1$ & 0 & NR & $\mathrm{NR}$ & 70 & 10 & 0 & 0 & 1 & 1 & \\
\hline 102 & 1.0 & $\stackrel{F}{N}$ & 8 & 5 & 1 & $<1$ & $\mathrm{NR}$ & $\mathrm{NR}$ & 95 & 10 & 0 & 0 & 2 & 0 & \\
\hline 103 & 5.7 & $\underset{N}{F}$ & 30 & 20 & 6 & 2 & 1.5 & 6.8 & 330 & 110 & $1600 \mathrm{~S}_{13}$ & $1300 \mathrm{~S}$ & 2 & 1 & \\
\hline 104 & 9.4 & $\stackrel{F}{N}$ & 25 & 25 & 4 & 5 & 2.8 & 3.0 & 130 & 70 & 15 & 12 & 5 & 4 & \\
\hline 105 & 5.2 & $\stackrel{F}{N}$ & 11 & 10 & 2 & 1 & NR & $\mathrm{NR}$ & 110 & 75 & 35 & 13 & 1 & 0 & \\
\hline 106 & 18.4 & $\stackrel{F}{N}$ & 210 & 12 & 70 & 1 & 2.8 & NR & 400 & 50 & 0 & 0 & 0 & 0 & \\
\hline 107 & 1.2 & $\stackrel{F}{N}$ & 39 & 41 & 15 & 10 & 0.4 & 0.8 & 160 & 90 & 120 & 100 & 35 & 30 & \\
\hline 108 & 1.2 & $\stackrel{F}{N}$ & 39 & 41 & 11 & 13 & 0.6 & 0.6 & 220 & 60 & 110 & 100 & 30 & 30 & \\
\hline 109 & 12.4 & $\stackrel{F}{N}$ & 183 & 168 & 66 & 5 & 0.9 & 18.2 & 270 & 120 & 0 & 0 & 1 & 0 & \\
\hline 110 & 23.2 & $\stackrel{F}{N}$ & $>660$ & 498 & 220 & 68 & 0.6 & 2.3 & 1000 & 280 & $1000 \mathrm{~s}$ & 700 & 20 & 10 & \\
\hline 111 & 11.0 & $\stackrel{F}{N}$ & 566 & 248 & 310 & 42 & 0.5 & 1.8 & 1100 & 180 & $600 \mathrm{~s}$ & $600 \mathrm{~s}$ & 19 & 8 & \\
\hline $112 \mathrm{~A}$ & 11.2 & $\stackrel{F}{N}$ & 40 & 4 & 12 & $<1$ & 2.6 & $\mathrm{NR}$ & 220 & 30 & 0 & 0 & 0 & 0 & $\begin{array}{l}\mathrm{SO}_{2}: 150 \\
\mathrm{SO}_{2}: 0\end{array}$ \\
\hline
\end{tabular}


Summary of Test Results; Smoke and Gas Concentration-Continued

\begin{tabular}{|c|c|c|c|c|c|c|c|c|c|c|c|c|c|c|c|}
\hline \multirow{3}{*}{$\begin{array}{l}\text { Sample } \\
\text { number }\end{array}$} & \multirow{3}{*}{$\begin{array}{c}\text { Specimen } \\
\text { weight }\end{array}$} & \multirow{3}{*}{$\begin{array}{c}\text { Test } \\
\text { Exposure } \\
F=\text { Flaming } \\
N=\text { Nonflaming }\end{array}$} & \multicolumn{6}{|c|}{ Smoke } & \multicolumn{7}{|c|}{ Gas concentration } \\
\hline & & & \multirow{2}{*}{\multicolumn{2}{|c|}{$\begin{array}{c}\text { Maximum } \\
\text { specific optical } \\
\text { density } \\
D_{m}\end{array}$}} & \multirow{2}{*}{\multicolumn{2}{|c|}{$\begin{array}{c}\text { Maximum } \\
\text { rate } \\
R_{m}\end{array}$}} & \multirow{2}{*}{\multicolumn{2}{|c|}{$\begin{array}{c}\text { Time to } \\
D_{s}=16 \\
t_{c}\end{array}$}} & \multicolumn{7}{|c|}{ Maximum indication, Colorimetric tube } \\
\hline & & & & & & & & & $\mathrm{CO}$ & & $\mathrm{HC}$ & & $\mathrm{HC}$ & & Others \\
\hline & $\theta$ & & & & & & $m i$ & & $p p r$ & & $p p r$ & & $p p$ & & $p p m$ \\
\hline 113 & 1.9 & $\begin{array}{l}F \\
N\end{array}$ & 4 & 4 & $<1$ & $<1$ & $\mathrm{NR}$ & $\mathrm{NR}$ & 60 & 5 & 0 & 0 & 0 & 0 & \\
\hline 114 & 1.6 & $\stackrel{F}{N}$ & 9 & 11 & 3 & 2 & $\mathrm{NR}$ & $\mathrm{NR}$ & 70 & 20 & 25 & 17 & 0 & 0 & \\
\hline 115 & 0.5 & $\stackrel{F}{N}$ & 0 & 0 & 0 & 0 & NR & $\mathrm{NR}$ & 60 & 5 & 0 & 0 & 0 & 0 & $\begin{array}{l}\text { HF: } 0 \\
\text { HF: } 0\end{array}$ \\
\hline 116 & 2.3 & $\stackrel{F}{N}$ & 6 & 3 & $<1$ & $<1$ & $\mathrm{NR}$ & $\mathrm{NR}$ & 70 & 15 & 0 & 0 & 0 & 0 & \\
\hline 117 & 9.5 & $\stackrel{F}{N}$ & 321 & 173 & 100 & 25 & 0.6 & 1.6 & 650 & 750 & $2000 \mathrm{~s}_{1}$ & $1100 \mathrm{~s}$ & 5 & 2 & \\
\hline $118 \mathrm{D}$ & 1.1 & $\stackrel{F}{N}$ & 15 & 0 & $<1$ & 0 & $\mathrm{NR}$ & $\mathrm{NR}$ & 280 & $<5$ & 0 & 0 & 1 & 0 & $\begin{array}{l}\text { HF: } 11 \\
\mathrm{HF}: 0\end{array}$ \\
\hline 119 & 1.0 & $\begin{array}{l}F \\
N\end{array}$ & 1 & 2 & $<1$ & $<1$ & $\mathrm{NR}$ & NR & 80 & 10 & 0 & 1 & 0 & 0 & \\
\hline 120 & 3.0 & $\stackrel{F}{N}$ & 1 & 1 & $<1$ & $<1$ & NR & $\mathrm{NR}$ & 90 & 10 & 11 & 10 & 0 & 0 & \\
\hline 121 & 12.2 & $\stackrel{F}{N}$ & 14 & 7 & $<1$ & $<1$ & $\mathrm{NR}$ & NR & 170 & 100 & 15 & 13 & 5 & 1 & \\
\hline 122 & 23.0 & $\stackrel{F}{N}$ & 125 & 66 & 30 & 13 & 1.1 & 3.2 & 800 & 700 & $2500 \mathrm{~s}$ & $2000 \mathrm{~s}$ & 1 & 1 & \\
\hline 123 & c 20.0 & $\begin{array}{l}F \\
N\end{array}$ & $>660$ & 508 & 290 & 120 & 0.2 & 0.3 & 1000 & 500 & 1100 & $1500 \mathrm{~s}$ & 8 & 6 & $\left\{\begin{array}{c}\mathrm{SO}_{2}: 45 \\
\mathrm{H}_{2} \mathrm{~S}: 40 \\
\mathrm{SO}_{2}: 40\end{array}\right.$ \\
\hline 124 & 1.9 & $\stackrel{F}{N}$ & 26 & 34 & 8 & 4 & 3.9 & 3.9 & 150 & 20 & 700 & 300 & 0 & 0 & \\
\hline 125 & 0.9 & $\stackrel{F}{N}$ & 2 & 1 & $<1$ & $<1$ & NR & NR & 60 & 10 & 0 & 0 & 0 & 0 & \\
\hline 126 & 0.9 & $\stackrel{F}{N}$ & 1 & 1 & $<1$ & $<1$ & NR & NR & 60 & 10 & 0 & 0 & 0 & 0 & \\
\hline 127 & 5.5 & $\stackrel{F}{N}$ & 309 & 162 & 250 & 45 & 0.4 & 1.0 & 380 & 100 & $700 \mathrm{~s}_{1}$ & $1000 \mathrm{~s}$ & 2 & 1 & \\
\hline $128 \mathrm{~A}$ & ' 4.2 & $\stackrel{F}{N}$ & 262 & 286 & 120 & 62 & 0.2 & 0.7 & 320 & 160 & 150 & 25 & 25 & 2 & \\
\hline $128 \mathrm{~B}$ & c 3.5 & $\begin{array}{l}F \\
N\end{array}$ & 41 & 300 & 15 & 54 & 0.6 & 0.7 & 150 & 190 & 2 & 2 & 2 & 2 & \\
\hline 129 & 20.1 & $\stackrel{F}{N}$ & 109 & 75 & 40 & 28 & 1.2 & 2.5 & 480 & 20 & 0 & 0 & 2 & 0 & $\begin{array}{l}\mathrm{HF}: 80 \\
\mathrm{HF}: 90\end{array}$ \\
\hline 130 & 16.7 & $\stackrel{F}{N}$ & 230 & 196 & 92 & 70 & 0.8 & 1.1 & 750 & 60 & $400 \mathrm{~s}$ & $200 \mathrm{~S}$ & 0 & 0 & $\begin{array}{l}\mathrm{SO}_{2}: 50 \\
\mathrm{SO}_{2}: 40\end{array}$ \\
\hline 131 & 18.8 & $\stackrel{F}{N}$ & 233 & 161 & 130 & 42 & 0.7 & 1.6 & 550 & 100 & 200 & $200 \mathrm{~S}$ & 5 & 2 & \\
\hline 132 & 1.8 & $\stackrel{F}{N}$ & 67 & 62 & 25 & 28 & 0.4 & 0.6 & 210 & 90 & $150 \mathrm{~s}$ & $100 \mathrm{~S}$ & 46 & 37 & \\
\hline 133 & 7.5 & $\stackrel{F}{N}$ & 503 & 218 & 300 & 57 & 0.4 & 1.3 & 500 & 80 & $800 \mathrm{~S}$ & $900 \mathrm{~s}$ & 1 & 0 & \\
\hline 134 & 5.6 & $\stackrel{F}{N}$ & 368 & 150 & 340 & 29 & 0.4 & 1.5 & 470 & 70 & $600 \mathrm{~s}$ & $350 \mathrm{~s}$ & 0 & 0 & \\
\hline 135 & 5.3 & $\underset{N}{\mathrm{~F}}$ & 170 & 94 & 83 & 30 & 0.4 & 1.0 & 200 & 70 & $600 \mathrm{~s}$ & $400 \mathrm{~S}$ & 1 & 1 & \\
\hline 136 & 18.3 & $\stackrel{F}{N}$ & 342 & 169 & 160 & 47 & 0.6 & 1.2 & 800 & 250 & $900 \mathrm{~s}$ & $500 \mathrm{~s}$ & 3 & 1 & \\
\hline 137 & 14.8 & $\stackrel{F}{N}$ & 440 & 154 & 140 & 41 & 0.5 & 1.7 & 620 & 120 & $1700 \mathrm{~S}$ & $800 \mathrm{~s}$ & 10 & 1 & \\
\hline 138 & 1.0 & $\stackrel{F}{N}$ & 10 & 9 & 2 & $<1$ & NR & NR & 100 & 40 & 0 & 0 & 4 & 2 & \\
\hline 139 & 1.5 & $\stackrel{F}{N}$ & 1 & 1 & $<1$ & $<1$ & NR & NR & 45 & $<5$ & 0 & 0 & 0 & 0 & $\begin{array}{l}\mathrm{HF}: 26 \\
\mathrm{HF}: 10\end{array}$ \\
\hline 140 & 2.4 & $\stackrel{F}{N}$ & 50 & 51 & 16 & 14 & 0.8 & 0.9 & 270 & 210 & 17 & 14 & 8 & 5 & $\mathrm{NO}+\mathrm{NO}_{2}: 8$ \\
\hline 141 & 5.4 & $\stackrel{F}{N}$ & 28 & 1 & 4 & $<1$ & 5.9 & NR & 180 & $<5$ & 0 & 0 & 0 & 0 & $\begin{array}{l}\mathrm{SO}_{2}: 30 \\
\mathrm{SO}_{2}: 0\end{array}$ \\
\hline
\end{tabular}


Summary of Test Results; Smoke and Gas Concentration-Continued

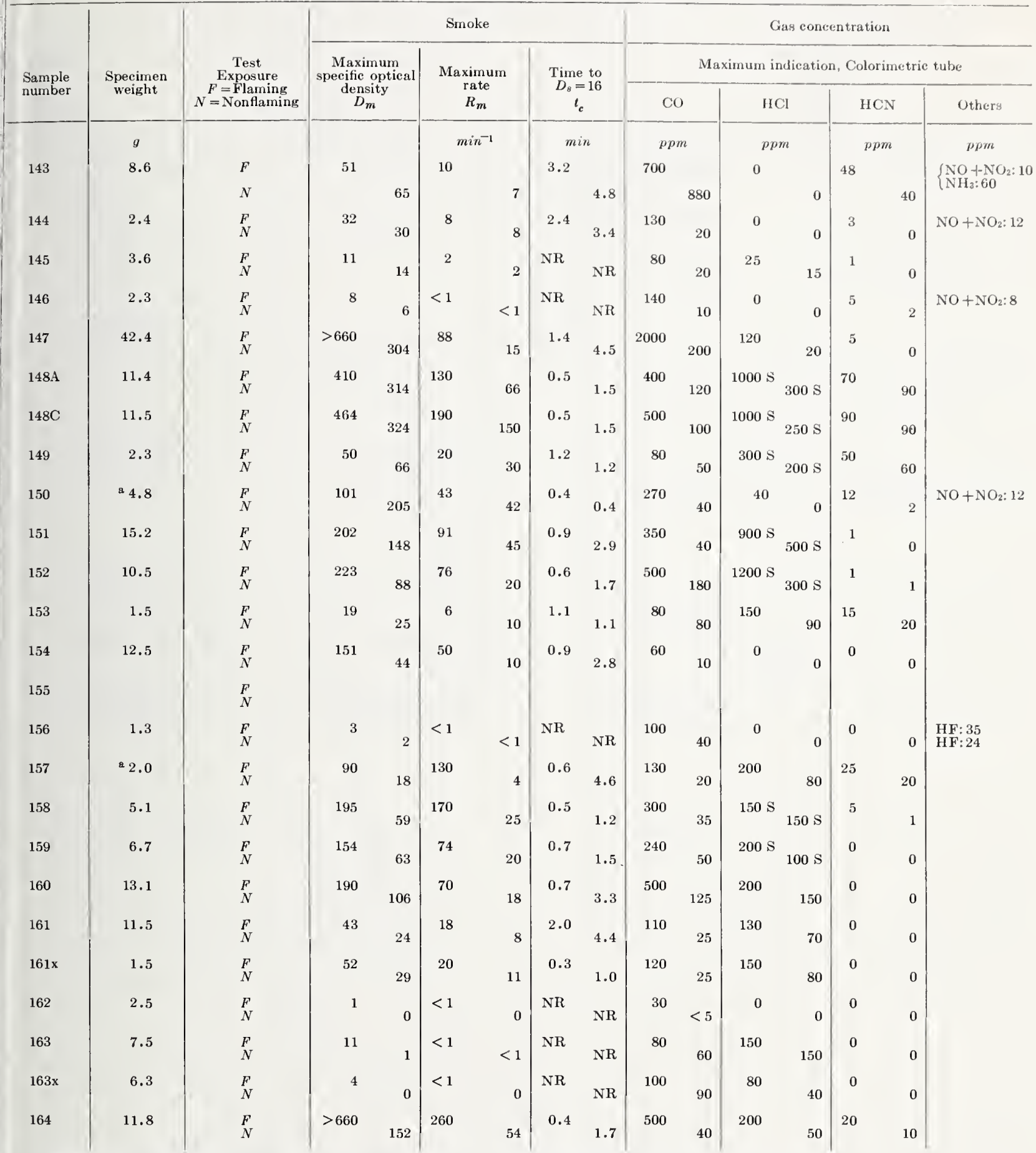

a Material not fully exposed because of melting, shrinking, etc.

b Tested in $5 / 8$-in. thickness.

NR Not reached.

c Tested in 1-in. thickness.

Measured with chloride ion electrode.

d Probably acrylonitrile vapor indication. 

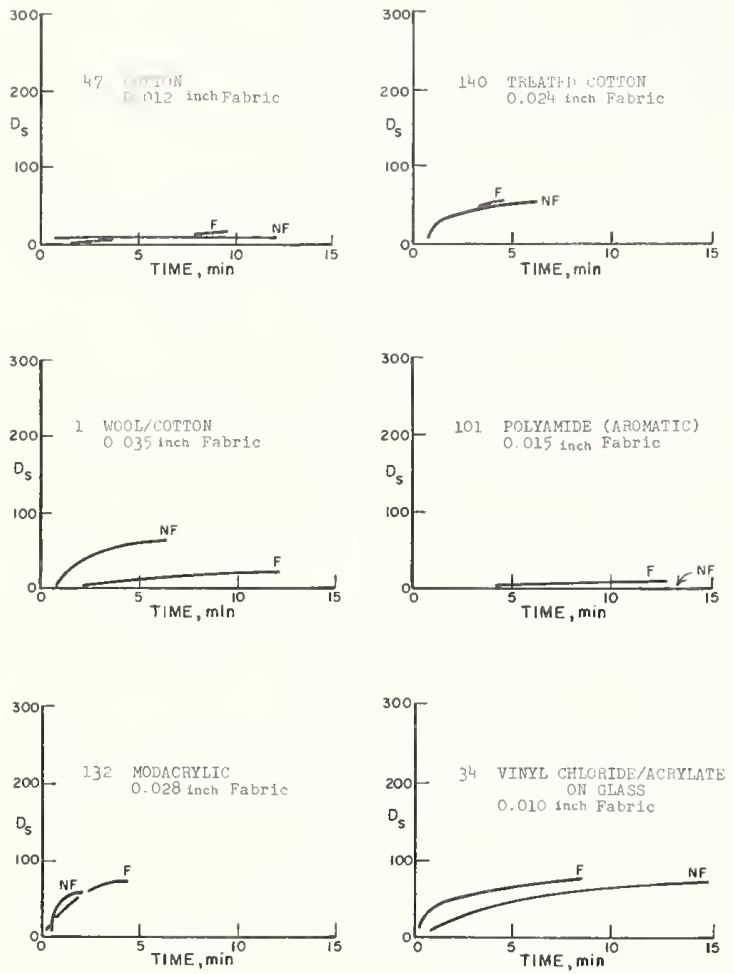

FIgURE 14. Typical smoke curves-fabrics.
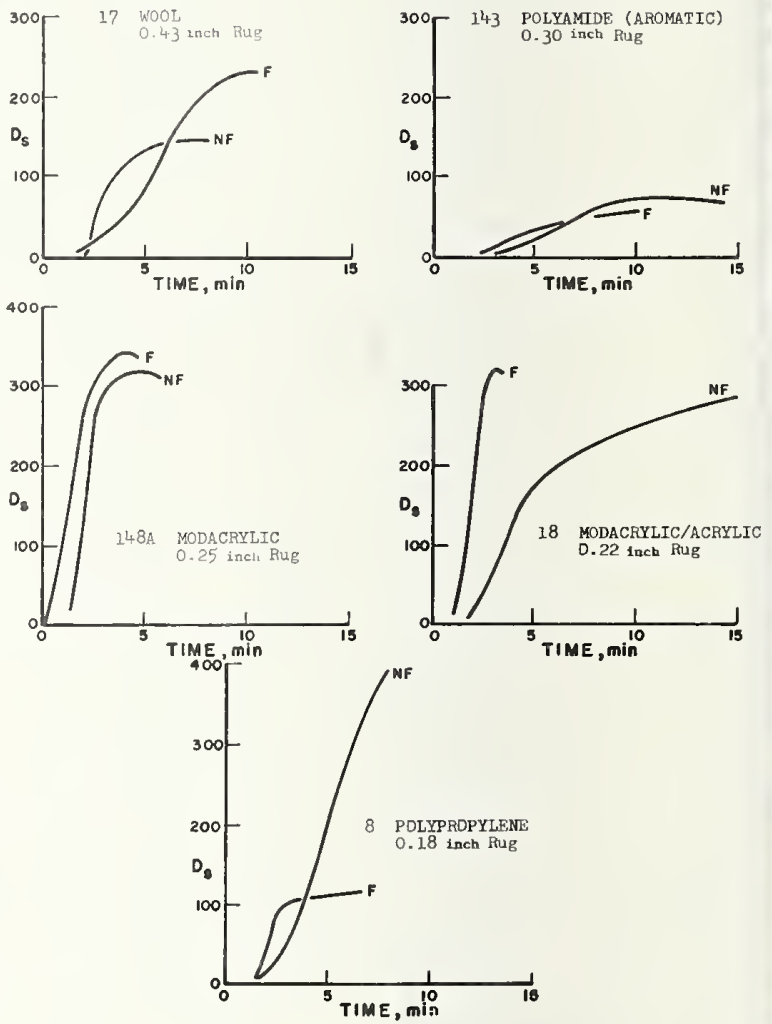

FIgure 15. Typical smoke curves-rugs. 

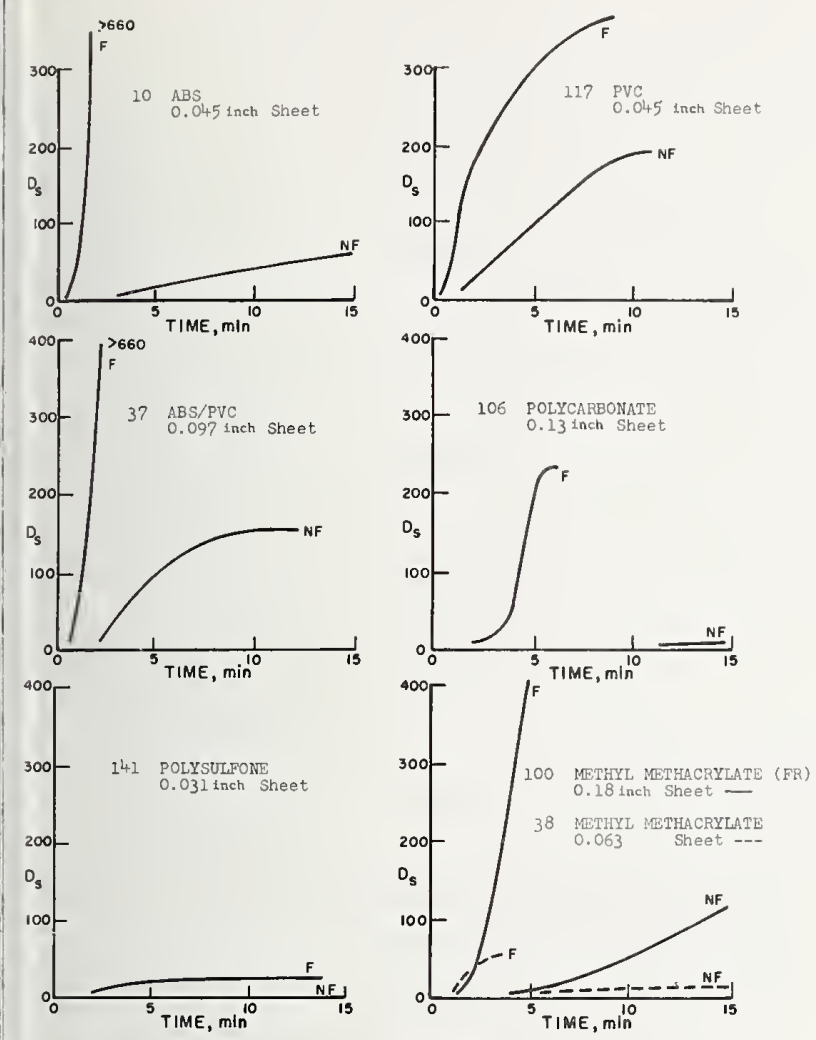

FIGURE 16. Typical smoke curves-sheets.
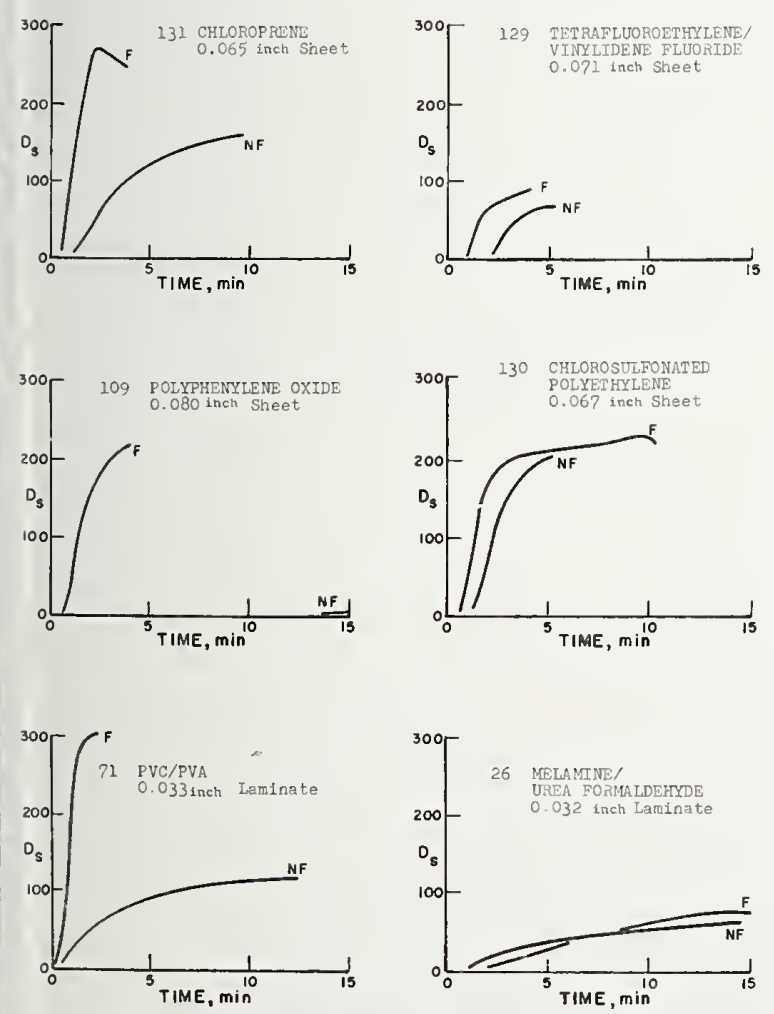

FIGURE 17. Typical smoke curves-sheets, laminates.
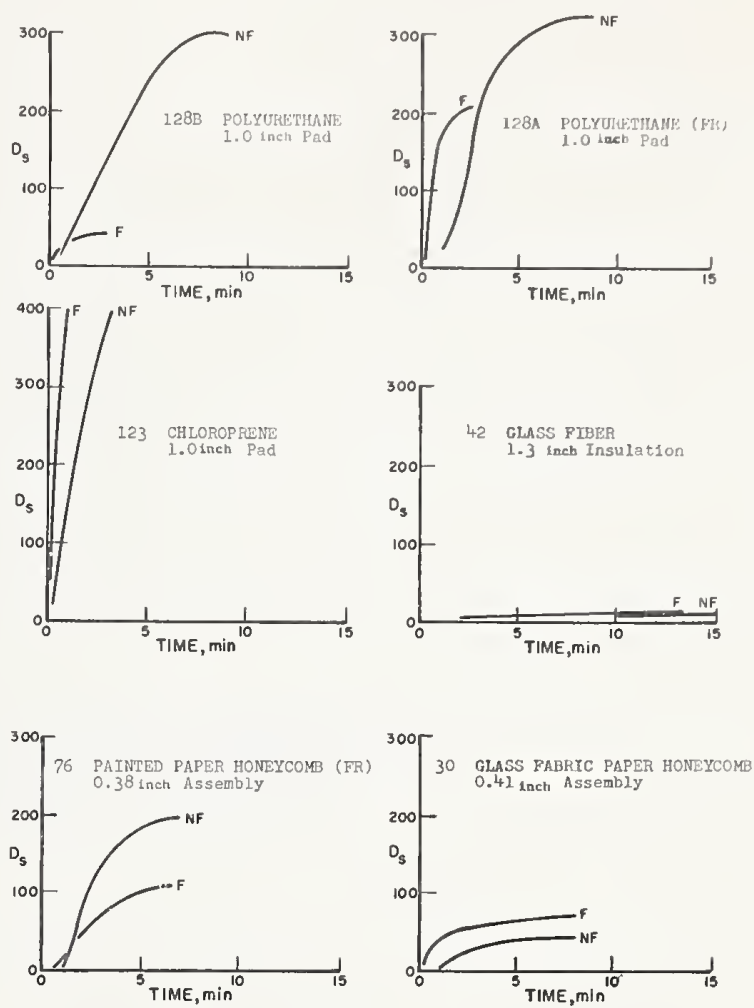

FIGURE 18. Typical smoke curves-pads, insulation, assemblies. 


\section{Announcement of New Publications in Building Science Series}

Superintendent of Documents,

Government Printing Office,

Washington, D.C., 20402

Dear Sir:

Please add my name to the announcement list of new publications to be issued in the series: National Bureau of Standards Building Science Series.

Name

Company

Address

City State Zip Code

(Notification key N-339) 


\section{NATIONAL BUREAU OF STANDARDS}

The National Bureau of Standards ${ }^{1}$ was established by an act of Congress March 3, 1901. Today, in addition to serving as the Nation's central measurement laboratory, the Bureau is a principal focal point in the Federal Government for assuring maximum application of the physical and engineering sciences to the advancement of technology in industry and commerce. To this end the Bureau conducts research and provides central national services in three broad program areas and provides central national services in a fourth. These are: (1) basic measurements and standards, (2) materials measurements and standards, (3) technological measurements and standards, and (4) transfer of technology.

The Bureau comprises the Institute for Basic Standards, the Institute for Materials Research, the Institute for Applied Technology, and the Center for Radiation Research.

THE INSTITUTE FOR BASIC STANDARDS provides the central basis within the United States of a complete and consistent system of physical measurement, coordinates that system with the measurement systems of other nations, and furnishes essential services leading to accurate and uniform physical measurements throughout the Nation's scientific community, industry, and commerce. The Institute consists of an Office of Standard Reference Data and a group of divisions organized by the following areas of science and engineering:

Applied Mathematics-Electricity-Metrology-Mechanics-Heat-Atomic Physics-Cryogenics ${ }^{2}$ - Radio Physics ${ }^{2}$-Radio Engineering ${ }^{2}$ - Astrophysics ${ }^{2}$-Time and Frequency. ${ }^{2}$

THE INSTITUTE FOR MATERIALS RESEARCH conducts materials research leading to methods, standards of measurement, and data needed by industry, commerce, educational institutions, and government. The Institute also provides advisory and research services to other government agencies. The Institute consists of an Office of Standard Reference Materials and a group of divisions organized by the following areas of materials research:

Analytical Chemistry-Polymers-Metallurgy — Inorganic Materials - Physical Chemistry.

THE INSTITUTE FOR APPLIED TECHNOLOGY provides for the creation of appropriate opportunities for the use and application of technology within the Federal Government and within the civilian sector of American industry. The primary functions of the Institute may be broadly classified as programs relating to technological measurements and standards and techniques for the transfer of technology. The Institute consists of a Clearinghouse for Scientific and Technical Information, ${ }^{3}$ a Center for Computer Sciences and Technology, and a group of technical divisions and offices organized by the following fields of technology:

Building Research-Electronic Instrumentation - Technical Analysis - Product

Evaluation-Invention and Innovation-Weights and Measures - Engineering

Standards-Vehicle Systems Research.

THE CENTER FOR RADIATION RESEARCH engages in research, measurement, and application of radiation to the solution of Bureau mission problems and the problems of other agencies and institutions. The Center for Radiation Research consists of the following divisions:

Reactor Radiation-Linac Radiation-Applied Radiation-Nuclear Radiation.

\footnotetext{
${ }^{1}$ Headquarters and Laboratories at Gaithersburg, Maryland, unless otherwise noted: mailing address Washington, D. C. 20234. 2 Located at Boulder, Colorado 80302.

${ }^{3}$ Located at 5285 Port Royal Road, Springfield, Virginia 22151.
} 
U.S. DEPARTMENT OF COMMERCE

WASHINGTON, D.C. 20230 